\title{
Exercise Training: The Holistic Approach in Cardiovascular Prevention
}

\author{
Francesco Giallauria ${ }^{1}$. Teresa Strisciuglio ${ }^{2}$. Gianluigi Cuomo ${ }^{1}$. Anna Di Lorenzo ${ }^{1}$ - Andrea D'Angelo ${ }^{1}$. \\ Mario Volpicelli ${ }^{3} \cdot$ Raffaele $\mathrm{Izzo}^{2} \cdot$ Maria Virginia Manzi $^{2} \cdot$ Emanuele Barbato $^{2} \cdot$ Carmine Morisco $^{2}$ (D)
}

Received: 30 September 2021 / Accepted: 23 October 2021 / Published online: 1 November 2021

(c) The Author(s) 2021

\begin{abstract}
Nowadays, there are robust clinical and pathophysiological evidence supporting the beneficial effects of physical activity on cardiovascular (CV) system. Thus, the physical activity is considered a key strategy for CV prevention. In fact, exercise training exerts favourable effects on all risk factors for CV diseases (i.e. essential hypertension, type 2 diabetes mellitus, hypercholesterolemia, obesity, metabolic syndrome, etc...). In addition, all training modalities such as the aerobic (continuous walking, jogging, cycling, etc.) or resistance exercise (weights), as well as the leisure-time physical activity (recreational walking, gardening, etc) prevent the development of the major CV risk factors, or delay the progression of target organ damage improving cardio-metabolic risk. Exercise training is also the core component of all cardiac rehabilitation programs that have demonstrated to improve the quality of life and to reduce morbidity in patients with CV diseases, mostly in patients with coronary artery diseases. Finally, it is still debated whether or not exercise training can influence the occurrence of atrial and ventricular arrhythmias. In this regard, there is some evidence that exercise training is protective predominantly for atrial arrhythmias, reducing the incidence of atrial fibrillation. In conclusion, the salutary effects evoked by physical acitvity are useful in primary and secondary $\mathrm{CV}$ prevention.
\end{abstract}

Keywords Type 2 diabetes $\cdot$ Insulin resistance $\cdot$ Sympathetic nervous system $\cdot$ Ischemic preconditioning $\cdot$ Physical activity $\cdot$ Leisure-time physical activity $\cdot$ Cardiac rehabilitation $\cdot$ Secondary prevention $\cdot$ Atrial fibrillation

\section{Introduction}

Cardiovascular (CV) prevention (primary and secondary) represent, nowadays, the principal objectives of the health care systems of the western countries. Usually, these goals are achieved through the control of the modifiable conventional $\mathrm{CV}$ risk factors, such as essential hypertension (EH), type 2 diabetes mellitus (T2D), hypercholesterolemia $(\mathrm{H})$, obesity (OB), metabolic syndrome (MS), etc. In the last decades, it has become evident that beside to

Francesco Giallauria and Teresa Strisciuglio equally contributed to the preparation of the manuscript.

Carmine Morisco

carmine.morisco@unina.it

1 Department of Translational Medical Sciences, "Federico II" University of Naples, 80131 Naples, Italy

2 Department of Advanced Biomedical Sciences, "Federico II" University of Naples, 80131 Naples, Italy

3 Department of Cardiology, "Santa Maria della Pietà" Hospital (ASL Napoli 3 Sud), 80035 Nola, NA, Italy the pharmacological control of these risk factors, also the lifestyle changes play a key role in the CV prevention. In particular, the reduction of alcoholic intake, the smoking cessation, the caloric and salt restrictions, the regular physical exercise, the nutrient supplements (vitamins, micronutrients, natural antioxidants) etc. have been demonstrated to contribute to the reduction of $\mathrm{CV}$ events; and nowadays are highly recommended by the Scientific Societies as valid tools in $\mathrm{CV}$ prevention.

The regular physical activity and the exercise training, in the past, were poor considered for CV prevention; and were suggested by the physicians as a merely advice. On the other hand, these lifestyle interventions met a very low compliance from the patients. Nowadays, the scenario is completely changed. In fact, there are robust clinical and pathophysiological evidence supporting the beneficial effects of physical activity on CV system. Thus, the physical activity is considered as a key strategy in CV prevention [1-4].

The present review aims at (a) highlighting the main exercise-induced pathophysiological mechanisms underlying $\mathrm{CV}$ protection, (b) resuming the most significant clinical 
findings regarding the beneficial effects of exercise training in primary $\mathrm{CV}$ prevention, (c) highlighting the role of exercise training in cardiac rehabilitation programs, and (d) reporting the still controversial effects of physical activity on arrhythmogenic burden.

\section{Pathophysiological Effects of Exercise on CV Homeostasis}

In the Western Countries, the sedentary lifestyle is a very common attitude that accounts directly or, indirectly for the enhanced cardio-metabolic risk. Exercise exerts favourable effects on several pathophysiological mechanisms that are involved the pathogenesis of CV and metabolic diseases. In particular, the regular physical activity exerts different metabolic, neuro-hormonal, vasorelaxant, anti-inflammatory, and antioxidant effects, that act in concert to reduce the $\mathrm{CV}$ risk.

Insulin resistance (IR) is defined as the reduced biological response to the hormone, and usually is due to a defect of the insulin signal transduction machinery [5]. IR is the main pathogenic mechanism of T2D, MS, OB; moreover, it plays a key role also in the pathogenesis of $\mathrm{EH}$, in the development and progression of target organ disease, and in the genesis of major CV events [6]. In general, IR can be considered as independent factor of $\mathrm{CV}$ risk. There are clear clinical and experimental evidence suggesting that exercise training interfere with the development of IR and improve insulin sensitivity [7]. This has several clinical implications, especially the prevention of T2D as well as its vascular complications. Low-grade chronic inflammation represents one of the principal mechanisms accounting for IR development; and, in general, for the increased CV risk [8]. Notably, the antiinflammatory effects induced by exercise training could be responsible for the improvement of insuline sensitivity [9], mediated by the improvement of the redox balance. In fact, the exercise training evokes also the increase of gene expression and the synthesis of antioxidative molecules [10, 11]. Finally, this effect determines also the improvement of the rheologic properties of the blood, an antiplatelet action, and the increased fibrinolytic action. Altogether these actions contribute to ameliorate the $\mathrm{CV}$ risk profile.

Dysregulation of sympathetic nervous system, resulting in an adrenergic overdrive, and adrenergic receptors desensitization, represents a further mechanism that account for the increased CV risk $[12,13]$ and adverse $\mathrm{CV}$ prognosis [14]. There is clear evidence suggesting that exercise training reduces the burden of sympathetic dysfunction improving CV prognosis [15], not only through an improvement of sympatho-vagal balance, but also through the reduction of arrhythmogenic risk.

Although it is still debated, a further determinant of CV risk is the vitamin $\mathrm{D}$ deficiency $[16,17]$. The principal sources of the vitamin D are the skin exposure to sun and diet. Thus, it is reasonable to hypothesize that the outdoor physical activities contribute to restore the levels of vitamin D. Noteworthly, it has been demonstrated that physical activity is associated with an increase of vitamin D levels, independently from sun exposure [18]. This indicates the pivotal role of the exercise in the vitamin D synthesis. In this regard, it has been proposed that exercise training stimulates the release of the vitamin from the adipose tissue storage [19].

Exercise training exerts cardioprotection also promoting more complex physiological processes such as the ischemic preconditioning (IP). This phenomenon consists in brief, repetitive, and sublethal ischemic stimuli. IP increases tolerance to a subsequent prolonged ischemic stress, and has a great pathophysiological relevance, since enhances the protection against the sustained ischemia-induced cell death to those organs that are composed of terminally differentiated cells, like brain and heart [20]. The remote preconditioning, is a feature of IP, and is defined as a protection from ischemia in one organ evoked by transient ischemia/reperfusion applied in a different (remote) organ [21]. Different molecules play a role of mediators of this phenomenon such as nitric oxide [22], opioids [23], adenosine [24], bradykinin [25]. There are experimental data that document the relevance of the remote ischemic precondition as mechanism that mediates the exercise-induced CV protection [26-28]. Interestingly, whereas IP and exercise training share many molecular pathways, the latter has been identified as a surrogate of IP [29].

In the Fig. 1 are summarized the principal mechanisms that account for the beneficial effects of the exercise training on CV system.

\section{Exercise and Primary CV Prevention}

The exercise exerts favourable effects on all determinants of $\mathrm{CV}$ risk. In particular, all forms of physical activities such as the aerobic (continuous walking, jogging, cycling, etc.) or resistance exercise (weights), as well as the leisure-time physical activity (LTPA) (recreational walking, gardening, etc.) have been demonstrated to prevent the development of the major $\mathrm{CV}$ risk factors, or to delay the progression of target organ damage, as well as to improve the cardiometabolic risk.

\subsection{Exercise and Type 2 Diabetes}

The most convincing evidence regarding the beneficial effects of exercise in primary $\mathrm{CV}$ prevention come from studies that involved individuals at high risk to develop T2D or with overt diabetic disease. In particular the Diabetes Prevention Program Research Group demonstrated in a 
Fig. 1 Principal pathophysiological changes evoked by exercise training that account for the reduction of $\mathrm{CV}$ risk. $N O$ nitric oxide, $H D L$ high density lipoprotein, $R P P$ rate pressure product, $\mathrm{O}_{2}$ oxygen

\section{EXERCISE TRAINING}

$\uparrow$ Synthesis, release, and duration of NO action

$\downarrow$ Low grade of chronic inflammation

$\downarrow$ Body weight and adiposity

$\downarrow$ Blood pressure and serum triglycerides

$\uparrow$ Plasma levels of HDL cholesterol

$\uparrow$ Insulin sensitivity and glucose homeostasis

$\downarrow$ RPP and myocardial $\mathrm{O}_{2}$ demands

$\uparrow$ Coronary artery compliance and elasticity

$\downarrow$ Arrythmogenic burden

$\uparrow$ Vitamin $D$ levels

$\uparrow$ Angiogenesis

$\uparrow$ Ischemic preconditioning and remote preconditioning

$\downarrow$ Sympathetic activity, $\uparrow$ vagal activity

$\downarrow$ Oxydative stress

$\uparrow$ Plasma volume, $\downarrow$ blood viscosity

$\uparrow$ Fibrinolytic activity, $\downarrow$ platelet aggregation

\section{REDUCTION OF CV RISK}

longitudinal study, that recruited 3234 nondiabetic persons with elevated fasting and post-load plasma glucose, that were randomly assigned to 3 different treatments: placebo, metformin and lifestyle-modification program, (this latter included moderate intensity physical activity), showed, during a mean follow-up of 2.8 years, that the lifestyle-modification program was able to reduce the incidence of the T2D by $58 \%$ [30]. These results were confirmed by the Finnish Diabetes Prevention [31], and by other post hoc-analysis and by longitudinal studies [32, 33]. The beneficial effects of physical activity were summarized in different metaanalyses that clearly demonstrated also favourable effect of the LTPA the in the prevention of T2D. In particular, the analysis of 28 prospective studies, showed a reduction of risk to develop T2D by $26 \%$ in those subjects who performed at least $150 \mathrm{~min} /$ week of moderate physical activity, compared to sedentary subjects [34]. To note, that in T2D, several meta-analyses have demonstrated that regular physical activity is able also to improve the glycemic control [35, $36]$, the lipid and hemodynamic profiles [9, 37], and inflammatory pattern [38].

Unfortunately, exercise benefits in reduction of major $\mathrm{CV}$ events incidence in subjects with T2D are not demonstrated by clear evidence. However, indirect evidence seem to indicate that in T2D patients exist an inverse relationship between cardiorespiratory fitness and mortality [39, 40].

\subsection{Exercise and Metabolic Syndrome}

$\mathrm{MS}$ is a cluster of $\mathrm{CV}$ risk factors and is an independent determinant of $\mathrm{CV}$ risk. The MS is the result of the sedentary behaviour, and is considered the typical feature of IR. To note, that unlike the T2D that affects mainly adult subjects, MS has high prevalence in adolescents and youngadult individuals. This has an important clinical implication in terms of CV risk, emphasizing the role of lifestyle changes could have as the main tool for the $\mathrm{CV}$ prevention. It has been documented the beneficial effect of exercise training or LTPA in the prevention of MS. A meta-analysis, that evaluated 17 prospective studies that recruited 64,353 participants, showed that high intensity of LTPA was associated with a reduction of risk to develop MS by $20 \%$ [41]. These data were confirmed by a further meta-analysis that documented that, not only high intensity, but any amount of LTPA was associated with a reduction of incident MS. In particular, a reduction of $8 \%$ of risk to develop MS for each 10 increments of metabolic equivalent of task (MET) $\mathrm{h}$ /week of LTPA was estimated [42]. In addition, it has been documented that the exercise training exerts the favourable effects interfering also against the single components of MS. In fact, it has been reported, in a randomized controlled trial, hat analyzed 51 men and 53 women that exercise training reduced total and abdominal obesity, and increased lean 
body mass, as well as ameliorated cholesterol-high density lipoproteins (HDL) and systolic blood pressure (SBP). At baseline, the criteria for the diagnosis of MS were present in $43.2 \%$ of the studied population, after 6 months of exercise training program, 17.7 and $15.1 \%$ in the exercise and in the control group, respectively, no longer had the criteria of MS [43]. Regarding the type of exercise, it has been reported that aerobic exercise, but not resistance exercise exerts a favorable effect on the all components of MS like waist circumference, fasting glucose, cholesterol-HDL, triglycerides and diastolic blood pressure (DBP) [44]. On the contrary, resistance exercise did not evoke any significant effect, However, it should be underlined that this notion could be due to limited data available.

\subsection{Exercise and Obesity}

$\mathrm{OB}$ is a key determinant of the CV risk. In fact, OB contributes to pathogenesis of all steps of continuum of CV disease, from development of cardiac hypertrophy [45] to the genesis of heart failure [46], from development of atherosclerosis [47], to the susceptibility of the atherosclerotic plaque [48] As for the T2D and MS, OB is an hallmark of the sedentary habits, and there is an inverse relationship between the physical activity and body mass index [49]. There are clear data that document in OB and overweight subjects the favorable effects of exercise training on weight reduction $[50,51]$. However, in these subjects the exercise activity cannot be considered the unique strategy for weight loss, since its effect resulted to be modest $(\approx 1.5 \mathrm{~kg})$. Interestingly, in $\mathrm{OB}$ individuals the exercise training rather than on weight loss, seems to be more efficacious to reduce BP, ameliorate the metabolic asset and the quality of life [52]. On the contrary, the exercise activity seems to play a key role in the weight loss maintenance [53]. In this regard, it has been documented by a meta-analysis, that revised the results of 33 trials, that the treatment based on diet + exercise training, was more efficacious than diet alone in the keeping the weight loss [54]. These data were confirmed by the National Weight Control Registry that demonstrated that that long-term weight-loss maintenance requires the integration of LTPA, with hypocaloric diet [55]. Altogether these studies underlined the relevance of exercise training in weight-loss maintenance. In this regard, the American College of Sports Medicine that indicated ".....after weight loss, weight maintenance is improved with physical activity $>250 \mathrm{~min} /$ weak" [56].

\subsection{Exercise and Lipid Profile}

Exercise training improves the lipid profile. High triglyceride (TG) levels are a feature of MS, and, as above mentioned, both exercise training and LTPA exert a favorable effect on the single components of the MS included the TG. The results of several studies are summarized in a recently published meta-analysis that analyzed the results of 48 studies, that included 2990 participants. The results of this analysis showed that the aerobic exercise training improved all lipid profile. Interestingly, the intensity of exercise was correlated with the reduction of TG, while the volume was associated with increase of HDL-cholesterol [57]. Nonalcoholic fatty liver disease (NAFLD) can be considered the hepatic manifestation of lipids disorder [58], and at the same time is an independent determinant of CV risk, To note that tit has been documented that the regular physical activity is also capable to improve the liver damage [59]. In particular, a recent meta-analysis that revised 15 controlled studies showed that aerobic exercise activity significantly improved the alanine aminotransferase (ALT) levels. This effect was associated with a reduction of intrahepatic TG and body mass index (BMI) [60], Low levels of cholesterol-HDL represent an independent risk factor for $\mathrm{CV}$ events. There are clear evidence that the exercise training is able to raise the levels of cholesterol-HDL. In particular, it has been demonstrated that the regular physical activity increases the plasma levels of HDL-cholesterol by 3-9\% [61]. Consistently, a meta-analysis that revised 35 studies showed that physical activity was the most important determinant of cholesterolHDL increase [62]. Beside these evidence, it has been also postulated the exercise training is also able to improve the function and metabolism of Cholesterol-HDL. However, this aspect needs to be deeper investigated. In summary, the beneficial effect of physical activity on the metabolic profile is an unquestionable clinical evidence.

\subsection{Exercise and Hypertension}

Exercise training exerts also favorable hemodynamic effects. In particular, it plays a role in the regulation of BP, in both normal subjects and in patients with EH. In particular, in a cross-sectional study it was documented that the physically active hypertensive patients had a lower 24-h and daytime DBP compared with the sedentary subjects [63]. The effects of exercise or the physical activity on office and ambulatory BP have been summarized in two meta-analyses. The first analysis that explored the effects of different types of exercise in 5223 individuals showed that all types of physical activities were able to reduce both office SBP and DBP. To note, that the magnitude of BP reduction, evoked training, was significantly higher in patients with $\mathrm{EH}(-8.3 /-5.2 \mathrm{mmHg}$ for SBP and DBP, respectively) in comparison with individuals with pre-hypertension $(-2.1 /-1.1 \mathrm{mmHg}$, for SBP and DBP) and normal subjects $(-0.75 /-1.1 \mathrm{mmHg}$ for SBP and DBP) [64]. A further analysis that included 633 participants documented that aerobic exercise significantly reduced both day-time SBP and DBP ( -3.2 and $-2.7 \mathrm{mmHg}$, respectively), conversely, it 
Table 1 Absolute changes of indexes of cardiovascular risk factors induced by exercise training

\begin{tabular}{ll}
\hline Parameter & \\
\hline HbA1c (\%) & -0.5 \\
Cholesterol-HDL (mg/dL) & +4 \\
Waist circumference (cm) & -3 \\
Diastolic blood pressure (mmHg) & -5 \\
Systolic blood pressure (mmHg) & -9 \\
Body weight (Kg) & -5 \\
\hline
\end{tabular}

$H b A l c$ glycated haemoglobin, $H D L$ high density lipoprotein

did not affect the night-time BP [65]. The favorable effects of exercise training are not limited to the prevention and management of EH but also positively affect also prognosis, including the reduction of mortality. In general, there is the evidence that LTPS is inversely associated with all-cause mortality in both men and women [66].

In summary, it has been well documented the favourable effects of exercise training in primary CV prevention (Table 1). In this regard, the Scientific Societies, highly recommend practicing at least $150 \mathrm{~min} /$ week of moderateintensity aerobic physical activity, or $75 \mathrm{~min} /$ week of highintensity activity [67].

\section{Exercise Training in Secondary CV Prevention}

Cardiac rehabilitation is a multidisciplinary, multifactorial and comprehensive intervention used as secondary prevention of CV diseases [68]. The core component of cardiac rehabilitation is the assessment of patient' class of risk [69] together with dietary advice [70, 71], educational intervention [72, 73], psychological support [74], exercise training [75] and therapy management [69]. Nowadays great progresses have been made in drug therapy [76-80], devices [81-86], and diagnostic technologies [87-90], which allow for an even greater reduction of some risk factors. However, to further reduce risk of new $\mathrm{CV}$ events, it is important to act not only on optimization of therapy and its adherence, but also on other risk factors such as OB and lifestyle [91-93]. Among cardiac rehabilitation elements, exercise training showed to play a key role in improving quality of life and reducing morbidity in patients with CV diseases [94-97].

\subsection{Pathophysiological Bases of Cardiac Rehabilitation}

Mechanisms investigated work on the one hand on cardiac function and remodeling, on the other hand on inflammation and autonomic system [98]. After myocardial infarction, a sequence of events begins, divided into early remodelling and late remodelling [99], which result in alteration of cardiac structure and function. A 6-month exercise training program showed to improve statistically significantly systolic and diastolic left ventricular function and volumes and to reduce serum levels of NT-proBNP [100, 101], which, such as brain natriuretic peptide (BNP), is released from ventricular chambers when it occurs increase in filling pressure [102, 103]. The importance of this reduction is even more considerable because these markers are recognized morbidity and mortality predictors in coronary heart disease patients $[104,105]$. Left atrium enlargement is a consequence of myocardial infarction, and it is predictive of atrial fibrillation onset, stroke and death [106, 107]. Exercise training proved to reduce, in addition to left ventricle, also left atrium remodelling and improve exercise capacity in patients with myocardial infarction [108].

About peripheral mechanism, adverse effects of adrenergic hyperactivation in cardiovascular diseases have been long investigated [109-111]. Several trials investigated exercise training capacity to reduce heart rate recovery (HRR) [112-114], i.e. heart rate fall in first minute after exercise, which is due to vagal tone increase and has been recognized as predictor of mortality in coronary heart disease patients $[115,116]$. These effects on prognosis could be explained by recognized benefits of parasympathetic tone increase in patients with myocardial infarction: heart rate reduction at rest leads to decrease of cardiac work and myocardial oxygen demand [117], and in addition circulating acetylcholine could reduce norepinephrine release and catecholamines receptor affinity $[118,119]$, reducing myocardial exposure to cytotoxic effects of noradrenalin excess.

Moreover, exercise training showed to reduce plasma concentration of high-mobility group box-1 (HMGB-1) [120-124], a protein expressed in quiescent cells which acts as a chromatin protein but is also involved in inflammatory process after released from necrotic cells [125]. Increased HMGB-1 levels have been investigated for association with negative inotropic effects [126], genesis of microvascular thrombosis [127] and worsening in remodelling of left ventricle [128]. So, evidence that exercise training could reduce HMGB-1 levels helps to clarify one of the many mechanisms by which cardiac rehabilitation contribute to improve favourable cardiac remodelling. Furthermore, reduction in proinflammatory cytokines concentration in skeletal muscle and increase of antioxidative molecules production are observed in patients who performed exercise training [129-131].

An important characteristic of coronary artery disease is endothelial dysfunction, which caused pathological vasoconstriction $[132,133]$ : exercise training showed to improve endothelial function through upregulation of endothelial nitric oxide expression and resulting increasing 
vasodilatation NO mediated [134, 135], also in patients with overt CV disease.

\subsection{Cardiac Rehabilitation in CV Diseases}

Favourable exercise training effects in coronary heart disease patients have been assessed also as regard to perfusion: patients enrolled in a 6-months exercise-based cardiac rehabilitation program early (about a week) after myocardial infarction showed a significant improvement in resting and stress wall motion and thickness at GATED-SPECT imaging [136, 137]. Different exercise training modalities have been investigated so far [138-147]. Before starting an exercise training program, a functional assessment (preferably using cardiopulmonary exercise testing) is indicated [148]. However, frail patients with CV diseases should be carefully evaluated by using specific tools [149-154]. Moderate continuous aerobic training is the oldest and most studied training modality $[155,156]$; performed by using cycling or treadmill for about $20-30$ min 2 or 3 times for week, maintaining a moderate intensity during effort (about $60-85 \%$ of peak heart rate or 11-14 on Borg scale) [148, 157]. Interval training is a kind of aerobic training which is generally performed using cycle ergometer, reaching high intensity (about $50-100 \%$ of peak $\mathrm{VO}_{2}$ or maximum heart rate) for duration from 30 seconds to 4 minutes, followed by a recovery phase, lasting for few minutes [148, 158]. Conraads et al. compared interval training and moderate continuous training effects in two-hundred patients with coronary artery disease: investigators found similar improvements in endothelial function (measured as flow mediated dilation of right brachial artery) and exercise capacity (measured as peak $\mathrm{VO}_{2}$ at CPET) in two groups [159].

Furthermore, interval training showed favourable ventricular remodelling, in addition to exercise capacity improvement, in patients with recent myocardial infarction [158]

A systematic review including 23 studies and 1117 patients (547 received high intensity interval training and 570 received moderate continuous training or usual care), investigated interval training safety in $\mathrm{CV}$ diseases patients [160]. In 11,333 training hours considered, only 1 major nonfatal CV adverse event (ventricular arrhythmia treating with electric cardioversion in a patient who refused cardioverter-defibrillator implantation before inclusion into the trial) occurred in interval training group, concluding that both interval and moderate continuous training appeared safe in patients with cardiovascular disease when performed in hospital setting. A different modality of training is resistance or strength training, which involves muscle contraction exercises against specific resistances, with aim of increase muscle mass and improve coordination [161].

Strength training alone showed to be effective and safe after myocardial infarction [162], but increasingly evidence suggest practicing in association to aerobic training to increase exercise capacity, muscle strength [163] and mobility in elderly patients with coronary artery disease [164].

Over the years, several meta-analyses have also been carried out to investigate effects of exercise training on mortality in patients with coronary artery disease.

The Cardiac Rehabilitation Outcome Study (CROS) in 2016 evaluated effectiveness of cardiac rehabilitation in patients with a recent cardiac event (were included studies about ACS, CABG or mixed population), treated with best actual therapies [165]: it demonstrated that cardiac rehabilitation was effective for reducing all-cause mortality, but not clear effects resulted for cardiovascular mortality and hospital readmissions, even if authors concluded that these last outcomes could be due to shift of potentially fatal reinfarctions to non-fatal events.

More recently, CROS-II meta-analyses, evaluating new evidences using the same inclusion criteria, confirmed the reduction in all-cause mortality in patients undergoing cardiac rehabilitation, showing in addition a favourable trend regarding cardiovascular mortality, but not clear trend were recognized about hospital readmission and cerebrovascular events [166]. However, a standardized protocol for cardiac rehabilitation should be defined in terms of training modality and duration. It could be reasonable that lifelong exercise training could attenuates left ventricular remodelling and other pathological consequences of myocardial infarction [167]. Notably, the effects of detraining evaluated in other cohorts of patients with increased cardiovascular risk showed that training suspension determine the loss of exercise-induced beneficial effects [168-175].

Therefore, studies providing long lasting and multifactorial cardiac rehabilitation programs were designed, aiming to reduce incidence of cardiovascular events following completion of rehabilitation and improve long term prognosis [176].

The multicenter randomized controlled GOSPEL trial showed reduction in cardiovascular mortality, nonfatal myocardial infarction and stroke in patients involved in a 3 -years long intensive cardiac rehabilitation program after myocardial infarction, compared to usual care [177]. Patients undergoing to longer cardiac rehabilitation programs showed to maintain improvement in CPET parameters and cardiovascular risk profile, while impairment in the same parameters are observed in other group of patients at the end of usual exercise training [178].

Therefore, based on the above-mentioned evidence, exercise-based cardiac rehabilitation should be tailored according to the characteristics and needs of the patient, trying to include more training modalities to prevent cardiac remodelling, and to improve functional capacity and quality of life. Furthermore, it would be advisable for the duration to be longer as possible, to better reduce $\mathrm{CV}$ events onset and improve prognosis. 


\section{Exercise Training and Cardiac Arrhythmias}

Physical activity has undeniable beneficial effects on the $\mathrm{CV}$ system and it also influences the cardiac electrical activity. Acutely, during exercise training, the release of catecholamines is responsible of the shortening of the action potential whereas in the long-term there is a parasympathetic tone enhancement and both conditions may enhance cardiac arrythmias [179].

Whether exercise training can influence the occurrence of atrial and ventricular arrhythmias has been a matter of debate. However, only for atrial arrhythmias there seems to be a protective effect whereas there are evidences supporting that physical activity can be a trigger for ventricular arrhythmias [180, 181].

\subsection{Exercise Training and Atrial Fibrillation}

As for the atrial arrhythmias, the relation of the exercise training with the atrial fibrillation (AF) has been the most investigated. The exercise training may include different activities and also different levels of intensity. In terms of cardiac excitability, there is a difference between endurance and strength exercise, indeed the former increases the oxygen uptake by increasing the heart rate and the cardiac output and decreasing the peripheral resistance, whereas the latter only modestly increases the cardiac output and greatly increases the peripheral resistance. These changes lead to a volume load for both ventricles in the endurance training and to a pressure load in the strength endurance [182].

Second, physical activity and AF are linked by a U-shaped relation, meaning that a moderate intensity of training can prevent $\mathrm{AF}$ whereas a more vigorous activity may promote this arrhythmia [183]. The study by Andersen et al. [184] is a large cohort study that investigated the incidence of $\mathrm{AF}$ and other arrhythmias over a 10 years follow-up period in 52,755 skiers who participated to the Vasaloppet, a $90 \mathrm{~km}$ cross-country skiing event. The investigators found higher incidence of AF and bradyarrhythmias in participants who completed more races and with faster finishing times, thus in more trained athletes, whereas no association with supra-ventricular tachycardia or ventricular tachycardia/ventricular fibrillation was found. These findings confirmed the results of previous case-control studies reporting that sport practice and in particular endurance sports represent a risk factor for the onset of lone AF [185-187]. The mechanisms leading to the onset of AF in the athlete's heart are several. First, endurance athletes have an enlargement of the left atrium diameter and of the left ventricular diameter related to an impaired diastolic function [188] as compared to controls. Second, the increased parasympathetic tone [189, 190] shortens the atrial refractory period and thereby facilitates re-entry and AF. Third, endurance athletes have greater atrial fibrosis [191] that at least in animal models is partially reversible after discontinuation of exercise training [192]. These changes that together account for the electrical and mechanical remodelling of the left atrium in athletes may be the substrate for the higher susceptibility to reentrant arrhythmias and in particular to AF. However, these changes can be observed only in highly trained individuals, whereas a moderate exercise has been proven to reduce the incidence of AF. The Cardiovascular Health Study [191] investigated the associations of leisure-time activity, exercise intensity, and walking habit with the incidence of AF in individuals $\geq 65$ years over a follow-up period of 12 years. Of note, walking distance and pace were each associated with lower AF risk in a graded manner. Similar results were found in a cohort of younger individuals included in the Troms $\varnothing$ Study [193]. The investigators found that among a Norwegian cohort of 20,484 adults followed for a period of 20 years the moderately active individuals had a $19 \%$ lower risk of any $\mathrm{AF}$ and furthermore that a resting heart rate $<50$ b.p.m. was a risk factor for AF. Furthermore, it is noteworthy that physical activity is able to partially offset in men the risk of AF related to excess body weight as demonstrated in the Atherosclerosis Risk in Communities study [194]. Accordingly, the Ford Exercise Testing (FIT) Project demonstrated that in obese patients there is an inverse relationship between cardiorespiratory fitness and incident AF [195]. This was a large cohort study including more than 6400 individuals free from AF at baseline and underwent a treadmill test. Over a median follow-up of 5.4 years the investigators found a substantial dose-response relationship with a 7\% lower risk of incident AF for every MET increase in cardio-respiratory fitness and the magnitude of the inverse association was greater among obese compared with nonobese individuals.

Lastly, exercise training may prevent the onset of AF by reducing $\mathrm{BP}$, promoting weight loss, reducing glycaemic levels; indeed $\mathrm{EH}, \mathrm{OB}$ and $\mathrm{T} 2 \mathrm{D}$ represent risk factors for the onset of $\mathrm{AF}$ as they contribute to atrial electrical and mechanical remodelling, that represents the substrate for reentries [196, 197].

As for the effect of exercise training in patients who have already been diagnosed with AF, a plenty of studies have been demonstrating clear benefits. First, in patients with non-permanent AF the burden of arrhythmia is reduced by an aerobic exercise training. The study by Malmo et al. [198] was a randomized trial that measured via a loop recorder the burden before and after 12 weeks of aerobic interval training (four 4-min intervals at $85-95 \%$ of peak heart rate 3 times 
a week) and demonstrated a marked reduction of the time in $\mathrm{AF}$, that was accompanied by a reduction of symptoms severity and frequency and by an improvement in left atrial and ventricular ejection fraction, lipid values and quality of life compared to controls. The most recent ACTIVE-AF trial assessed the impact of a 6-month exercise programme combining supervised and home-based aerobic exercise on AF recurrence and symptom severity. The study included 120 patients with paroxysmal or persistent AF that were randomly assigned to the exercise intervention or to usual care. In the exercise group there was a lower rate of AF recurrence at 12 months and also a reduction of severity symptoms [in press]. Notably, exercise training in patient with $\mathrm{AF}$ is also associated with a reduction of hard outcomes such as all cause death as demonstrated by Proietti et al. [199]. In particular, among 2442 patients enrolled in the EURObservational Research Programme on AF (EORPAF) Pilot Survey, lower rates of CV death, all-cause death, and composite outcomes were found in AF patients who reported regular and intense physical activity. Furthermore, the association between physical activity and the reduced risk of all- cause death was significant regardless of gender, older age ( $\geq 75$ years), presence of paroxysmal AF, and high thromboembolic risk (CHA2DS2-VASc score $\geq 2$ ). A supposed mechanism is exercise capacity to improve $\mathrm{VO}_{2}$ peak (a known prognostic factor) in patients with chronic $\mathrm{AF}$ suggesting that physical activity may be therapeutical in $\mathrm{AF}$ patients [200, 201].

Acknowledgements The authors are grateful to Federica De Luise for her assistance with manuscript preparation.

\section{Declarations}

Funding None.

\section{Conflict of interest None.}

Availability of data and material Findings were gathered from the published articles in the literature.

Author contributions FG, TS and CM had the idea for this article; RI, MVM, CG, DLA, performed the literature search; DA, VM, FG, TS, $\mathrm{CM}$ drafted the manuscript; and EB critically revised the work.

Open Access This article is licensed under a Creative Commons Attribution-NonCommercial 4.0 International License, which permits any non-commercial use, sharing, adaptation, distribution and reproduction in any medium or format, as long as you give appropriate credit to the original author(s) and the source, provide a link to the Creative Commons licence, and indicate if changes were made. The images or other third party material in this article are included in the article's Creative Commons licence, unless indicated otherwise in a credit line to the material. If material is not included in the article's Creative Commons licence and your intended use is not permitted by statutory regulation or exceeds the permitted use, you will need to obtain permission directly from the copyright holder. To view a copy of this licence, visit http://creativecommons.org/licenses/by-nc/4.0/.

\section{References}

1. Jensen MD, Ryan DH, Apovian CM, Ard JD, Comuzzie AG, Donato KA, Hu FB, Hubbard VS, Jakicic JM, Kushner RF, Loria CM, Millen BE, Nonas CA, Pi-Sunyer FX, Stevens J, Stevens VJ, Wadden TA, Wolfe BM, Yanovski SZ, American College of Cardiology/American Heart Association Task Force on Practice Guidelines, Obesity Society. 2013 AHA/ACC/TOS guideline for the management of overweight and obesity in adults: a report of the American College of Cardiology/American Heart Association Task Force on Practice Guidelines and The Obesity Society. J Am Coll Cardiol. 2014;63(25 Pt B):2985-3023. https://doi.org/ 10.1016/j.jacc.2013.11.004 (Epub 2013 Nov 12 Erratum in: J Am Coll Cardiol. 2014 Jul 1;63(25 Pt B):3029-3030. PMID: 24239920).

2. Authors/Task Force Members, Piepoli MF, Hoes AW, Agewall S, Albus C, Brotons C, Catapano AL, Cooney MT, Corrà U, Cosyns B, Deaton C, Graham I, Hall MS, Hobbs FDR, Løchen ML, Löllgen H, Marques-Vidal P, Perk J, Prescott E, Redon J, Richter DJ, Sattar N, Smulders Y, Tiberi M, Bart van der Worp H, van Dis I, Verschuren WMM. 2016 European guidelines on cardiovascular disease prevention in clinical practice: the Sixth Joint Task Force of the European Society of Cardiology and Other Societies on Cardiovascular Disease Prevention in Clinical Practice (constituted by representatives of 10 societies and by invited experts) Developed with the special contribution of the European Association for Cardiovascular Prevention and Rehabilitation (EACPR). Atherosclerosis. 2016;2016(252):207-74. https://doi.org/10.1016/j.atherosclerosis.2016.05.037.

3. Williams B, Mancia G, Spiering W, Agabiti Rosei E, Azizi M, Burnier M, Clement DL, Coca A, de Simone G, Dominiczak A, Kahan T, Mahfoud F, Redon J, Ruilope L, Zanchetti A, Kerins M, Kjeldsen SE, Kreutz R, Laurent S, Lip GYH, McManus R, Narkiewicz K, Ruschitzka F, Schmieder RE, Shlyakhto E, Tsioufis C, Aboyans V, Desormais I. Authors/Task Force Members: 2018 ESC/ESH guidelines for the management of arterial hypertension: the Task Force for the management of arterial hypertension of the European Society of Cardiology and the European Society of Hypertension: the Task Force for the management of arterial hypertension of the European Society of Cardiology and the European Society of Hypertension. J Hypertens. 2018;36(10):1953-2041.

4. Volpe M, Gallo G, Battistoni A, Tocci G. Highlights of ESC/ ESH 2018 guidelines on the management of hypertension: what every doctor should know. High Blood Press Cardiovasc Prev. 2019;26(1):1-8. https://doi.org/10.1007/s40292-018-00297-y (Epub 2019 Jan 2).

5. Morisco C, Lembo G, Trimarco B. Insulin resistance and cardiovascular risk: new insights from molecular and cellular biology. Trends Cardiovasc Med. 2006;16(6):183-8. https://doi.org/10. 1016/j.tcm.2006.03.008.

6. Mancusi C, Izzo R, di Gioia G, Losi MA, Barbato E, Morisco C. Insulin resistance the hinge between hypertension and type 2 diabetes. High Blood Press Cardiovasc Prev. 2020;27(6):515-26. https://doi.org/10.1007/s40292-020-00408-8 (Epub 2020 Sep 22).

7. Iaccarino G, Franco D, Sorriento D, Strisciuglio T, Barbato E, Morisco C. Modulation of insulin sensitivity by exercise training: implications for cardiovascular prevention. J Cardiovasc Transl 
Res. 2021;14(2):256-70. https://doi.org/10.1007/s12265-02010057-w (Epub 2020 Jul 31).

8. Fiordelisi A, Iaccarino G, Morisco C, Coscioni E, Sorriento D. NFkappaB is a key player in the crosstalk between inflammation and cardiovascular diseases. Int J Mol Sci. 2019;20(7):1599. https://doi.org/10.3390/ijms20071599.

9. Lin X, Zhang X, Guo J, Roberts CK, McKenzie S, Wu WC, Liu S, Song Y. Effects of exercise training on cardiorespiratory fitness and biomarkers of cardiometabolic health: a systematic review and meta-analysis of randomized controlled trials. J Am Heart Assoc. 2015;4(7): e002014. https://doi.org/10.1161/JAHA. 115.002014.

10. Ennezat PV, Malendowicz SL, Testa M, Colombo PC, CohenSolal A, Evans T, LeJemtel TH. Physical training in patients with chronic heart failure enhances the expression of genes encoding antioxidative enzymes. J Am Coll Cardiol. 2001;38(1):194-8. https://doi.org/10.1016/s0735-1097(01)01321-3.

11. Linke A, Adams V, Schulze PC, Erbs S, Gielen S, Fiehn E, Möbius-Winkler S, Schubert A, Schuler G, Hambrecht R. Antioxidative effects of exercise training in patients with chronic heart failure: increase in radical scavenger enzyme activity in skeletal muscle. Circulation. 2005;111(14):1763-70. https://doi. org/10.1161/01.CIR.0000165503.08661.E5 (Epub 2005 Apr 4).

12. Quarti Trevano F, Dell'Oro R, Biffi A, Seravalle G, Corrao G, Mancia G, Grassi G. Sympathetic overdrive in the metabolic syndrome: meta-analysis of published studies. J Hypertens. 2020;38(4):565-72. https://doi.org/10.1097/HJH.0000000000 002288 .

13. Grassi G. The sympathetic nervous system in hypertension: roadmap update of a long journey. Am J Hypertens. 2021. https://doi. org/10.1093/ajh/hpab124 (Epub ahead of print).

14. Swedberg K, Eneroth P, Kjekshus J, Wilhelmsen L. Hormones regulating cardiovascular function in patients with severe congestive heart failure and their relation to mortality. CONSENSUS Trial Study Group. Circulation. 1990;82(5):1730-6. https://doi. org/10.1161/01.cir.82.5.1730.

15. Roveda F, Middlekauff HR, Rondon MU, Reis SF, Souza M, Nastari L, Barretto AC, Krieger EM, Negrão CE. The effects of exercise training on sympathetic neural activation in advanced heart failure: a randomized controlled trial. J Am Coll Cardiol. 2003;42(5):854-60. https://doi.org/10.1016/s0735-1097(03) 00831-3.

16. Scragg R, Sowers M, Bell C. Serum 25-hydroxyvitamin D, ethnicity, and blood pressure in the Third National Health and Nutrition Examination Survey. Am J Hypertens. 2007;20(7):713-9. https://doi.org/10.1016/j.amjhyper.2007.01.017.

17. Wang TJ, Pencina MJ, Booth SL, Jacques PF, Ingelsson E, Lanier K, Benjamin EJ, D'Agostino RB, Wolf M, Vasan RS. Vitamin $\mathrm{D}$ deficiency and risk of cardiovascular disease. Circulation. 2008;117(4):503-11. https://doi.org/10.1161/CIRCULATIO NAHA.107.706127 (Epub 2008 Jan 7).

18. Scragg R, Camargo CA Jr. Frequency of leisure-time physical activity and serum 25 -hydroxyvitamin D levels in the US population: results from the Third National Health and Nutrition Examination Survey. Am J Epidemiol. 2008;168(6):577-86. https://doi. org/10.1093/aje/kwn163 (discussion 587-91; Epub 2008 Jun 25).

19. Sun X, Cao ZB, Taniguchi H, Tanisawa K, Higuchi M. Effect of an acute bout of endurance exercise on serum $25(\mathrm{OH})$ $\mathrm{D}$ concentrations in young adults. J Clin Endocrinol Metab. 2017;102(11):3937-44. https://doi.org/10.1210/jc.2017-00146.

20. Bellis A, Castaldo D, Trimarco V, Monti MG, Chivasso P, Sadoshima J, Trimarco B, Morisco C. Cross-talk between PKA and Akt protects endothelial cells from apoptosis in the late ischemic preconditioning. Arterioscler Thromb Vasc Biol.
2009;29(8):1207-12. https://doi.org/10.1161/ATVBAHA.109. 184135 (Epub 2009 May 21).

21. Bellis A, Di Gioia G, Mauro C, Mancusi C, Barbato E, Izzo R, Trimarco B, Morisco C. Reducing cardiac injury during STelevation myocardial infarction: a reasoned approach to a multitarget therapeutic strategy. J Clin Med. 2021;10(13):2968. https:// doi.org/10.3390/jcm10132968.

22. Tokuno S, Hinokiyama K, Tokuno K, Löwbeer C, Hansson LO, Valen G. Spontaneous ischemic events in the brain and heart adapt the hearts of severely atherosclerotic mice to ischemia. Arterioscler Thromb Vasc Biol. 2002;22(6):995-1001. https:// doi.org/10.1161/01.atv.0000017703.87741.12.

23. Randhawa PK, Jaggi AS. Opioids in remote ischemic preconditioning-induced cardioprotection. J Cardiovasc Pharmacol Ther. 2017;22(2):112-21. https://doi.org/10.1177/1074248416660621 (Epub 2016 Jul 28).

24. Randhawa PK, Jaggi AS. Unraveling the role of adenosine in remote ischemic preconditioning-induced cardioprotection. Life Sci. 2016;15(155):140-6. https://doi.org/10.1016/j.lfs.2016.05. 009 (Epub 2016 May 6).

25. Bellis A, Sorriento D, Fiordelisi A, Izzo R, Sadoshima J, Mauro C, Cerasuolo F, Mancusi C, Barbato E, Pilato E, Trimarco B, Morisco C. Autocrine bradykinin release promotes ischemic preconditioning-induced cytoprotection in bovine aortic endothelial cells. Int J Mol Sci. 2020;21(8):2965. https://doi.org/10.3390/ ijms21082965.

26. Santana MNS, Souza DS, Miguel-Dos-Santos R, Rabelo TK, Vasconcelos CML, Navia-Pelaez JM, Jesus ICG, Silva-Neto JAD, Lauton-Santos S, Capettini LDSA, Guatimosim S, Rogers RG, Santos MRVD, Santana-Filho VJ, Mesquita TRR. Resistance exercise mediates remote ischemic preconditioning by limiting cardiac eNOS uncoupling. J Mol Cell Cardiol. 2018;125:6172. https://doi.org/10.1016/j.yjmcc.2018.10.016 (Epub 2018 Oct 16).

27. Seeger JP, Lenting CJ, Schreuder TH, Landman TR, Cable NT, Hopman MT, Thijssen DH. Interval exercise, but not endurance exercise, prevents endothelial ischemia-reperfusion injury in healthy subjects. Am J Physiol Heart Circ Physiol. 2015;308(4):H351-7. https://doi.org/10.1152/ajpheart.00647. 2014 (Epub 2014 Nov 21).

28. Michelsen MM, Støttrup NB, Schmidt MR, Løfgren B, Jensen RV, Tropak M, St Michel EJ, Redington AN, Bøtker HE. Exercise-induced cardioprotection is mediated by a bloodborne, transferable factor. Basic Res Cardiol. 2012;107(3):260. https://doi. org/10.1007/s00395-012-0260-x (Epub 2012 Mar 18).

29. Chowdhury MA, Sholl HK, Sharrett MS, Haller ST, Cooper CC, Gupta R, Liu LC. Exercise and cardioprotection: a natural defense against lethal myocardial ischemia-reperfusion injury and potential guide to cardiovascular prophylaxis. J Cardiovasc Pharmacol Ther. 2019;24(1):18-30. https://doi.org/10.1177/ 1074248418788575 (Epub 2018 Jul 24).

30. Knowler WC, Barrett-Connor E, Fowler SE, Hamman RF, Lachin JM, Walker EA, Nathan DM, Diabetes Prevention Program Research Group. Reduction in the incidence of type 2 diabetes with lifestyle intervention or metformin. N Engl J Med. 2002;346(6):393-403. https://doi.org/10.1056/NEJMoa012512.

31. Tuomilehto J, Lindström J, Eriksson JG, Valle TT, Hämäläinen $\mathrm{H}$, Ilanne-Parikka P, Keinänen-Kiukaanniemi S, Laakso M, Louheranta A, Rastas M, Salminen V, Uusitupa M, Finnish Diabetes Prevention Study Group. Prevention of type 2 diabetes mellitus by changes in lifestyle among subjects with impaired glucose tolerance. N Engl J Med. 2001;344(18):1343-50. https:// doi.org/10.1056/NEJM200105033441801.

32. Laaksonen DE, Lindström J, Lakka TA, Eriksson JG, Niskanen L, Wikström K, Aunola S, Keinänen-Kiukaanniemi S, Laakso M, Valle TT, Ilanne-Parikka P, Louheranta A, Hämäläinen H, 
Rastas M, Salminen V, Cepaitis Z, Hakumäki M, Kaikkonen H, Härkönen P, Sundvall J, Tuomilehto J, Uusitupa M, Finnish Diabetes Prevention Study. Physical activity in the prevention of type 2 diabetes: the Finnish diabetes prevention study. Diabetes. 2005;54(1):158-65. https://doi.org/10.2337/diabetes.54.1.158.

33. Hu FB, Sigal RJ, Rich-Edwards JW, Colditz GA, Solomon CG, Willett WC, Speizer FE, Manson JE. Walking compared with vigorous physical activity and risk of type 2 diabetes in women: a prospective study. JAMA. 1999;282(15):1433-9. https://doi. org/10.1001/jama.282.15.1433.

34. Smith AD, Crippa A, Woodcock J, Brage S. Physical activity and incident type 2 diabetes mellitus: a systematic review and dose-response meta-analysis of prospective cohort studies. Diabetologia. 2016;59(12):2527-45. https://doi.org/10.1007/s00125016-4079-0 (Epub 2016 Oct 17).

35. Jang JE, Cho Y, Lee BW, Shin ES, Lee SH. Effectiveness of exercise intervention in reducing body weight and glycosylated hemoglobin levels in patients with type 2 diabetes mellitus in Korea: A systematic review and meta-analysis. Diabetes Metab J. 2019;43(3):302-18. https://doi.org/10.4093/dmj.2018.0062 (Epub 2018 Nov 19).

36. Boniol M, Dragomir M, Autier P, Boyle P. Physical activity and change in fasting glucose and HbAlc: a quantitative meta-analysis of randomized trials. Acta Diabetol. 2017;54(11):983-91. https://doi.org/10.1007/s00592-017-1037-3 (Epub 2017 Aug 24).

37. Hayashino Y, Jackson JL, Fukumori N, Nakamura F, Fukuhara S. Effects of supervised exercise on lipid profiles and blood pressure control in people with type 2 diabetes mellitus: a metaanalysis of randomized controlled trials. Diabetes Res Clin Pract. 2012;98(3):349-60. https://doi.org/10.1016/j.diabres.2012.10. 004 (Epub 2012 Oct 29).

38. Hayashino Y, Jackson JL, Hirata T, Fukumori N, Nakamura F, Fukuhara S, Tsujii S, Ishii H. Effects of exercise on C-reactive protein, inflammatory cytokine and adipokine in patients with type 2 diabetes: a meta-analysis of randomized controlled trials. Metabolism. 2014;63(3):431-40. https://doi.org/10.1016/j.metab ol.2013.08.018 (Epub 2013 Nov 23).

39. Wei M, Gibbons LW, Kampert JB, Nichaman MZ, Blair SN. Low cardiorespiratory fitness and physical inactivity as predictors of mortality in men with type 2 diabetes. Ann Intern Med. 2000;132(8):605-11. https://doi.org/10.7326/0003-4819-132-8200004180-00002.

40. Church TS, Cheng YJ, Earnest CP, Barlow CE, Gibbons LW, Priest EL, Blair SN. Exercise capacity and body composition as predictors of mortality among men with diabetes. Diabetes Care. 2004;27(1):83-8. https://doi.org/10.2337/diacare.27.1.83.

41. He D, Xi B, Xue J, Huai P, Zhang M, Li J. Association between leisure time physical activity and metabolic syndrome: a meta-analysis of prospective cohort studies. Endocrine. 2014;46(2):231-40. https://doi.org/10.1007/s12020-013-01100 (Epub 2013 Nov 28).

42. Zhang D, Liu X, Liu Y, Sun X, Wang B, Ren Y, Zhao Y, Zhou J, Han C, Yin L, Zhao J, Shi Y, Zhang M, Hu D. Leisure-time physical activity and incident metabolic syndrome: a systematic review and dose-response meta-analysis of cohort studies. Metabolism. 2017;75:36-44. https://doi.org/10.1016/j.metabol. 2017.08.001 (Epub 2017 Aug 15).

43. Stewart KJ, Bacher AC, Turner K, Lim JG, Hees PS, Shapiro EP, Tayback M, Ouyang P. Exercise and risk factors associated with metabolic syndrome in older adults. Am J Prev Med. 2005;28(1):9-18. https://doi.org/10.1016/j.amepre.2004.09.006.

44. Wewege MA, Thom JM, Rye KA, Parmenter BJ. Aerobic, resistance or combined training: a systematic review and meta-analysis of exercise to reduce cardiovascular risk in adults with metabolic syndrome. Atherosclerosis. 2018;274:162-71. https://doi.org/10. 1016/j.atherosclerosis.2018.05.002 (Epub 2018 May 3).

45. Buono F, Crispo S, Pagano G, Rengo G, Petitto M, Grieco F, Trimarco B, Morisco C. Determinants of left ventricular hypertrophy in patients with recent diagnosis of essential hypertension. J Hypertens. 2014;32(1):166-73. https://doi.org/10.1097/HJH. $0 \mathrm{~b} 013 \mathrm{e} 328365 \mathrm{c} 87 \mathrm{~d}$.

46. Kenchaiah S, Evans JC, Levy D, Wilson PW, Benjamin EJ, Larson MG, Kannel WB, Vasan RS. Obesity and the risk of heart failure. N Engl J Med. 2002;347(5):305-13. https://doi.org/10. 1056/NEJMoa020245

47. Imahori Y, Mathiesen EB, Morgan KE, Frost C, Hughes AD, Hopstock LA, Johnsen SH, Emaus N, Leon DA. The association between anthropometric measures of adiposity and the progression of carotid atherosclerosis. BMC Cardiovasc Disord. 2020;20(1):138. https://doi.org/10.1186/s12872-020-01417-0.

48. Kato M, Dote K, Naganuma T, Sasaki S, Ueda K, Okita M, Watanabe Y, Kajikawa M, Yokoyama H, Higashi A. Clinical predictors of culprit plaque rupture assessed on intravascular ultrasound in acute coronary syndrome. Circ J. 2010;74(9):1936-42. https:// doi.org/10.1253/circj.cj-10-0086 (Epub 2010 Jul 8).

49. Bhupathiraju SN, Hu FB. Epidemiology of obesity and diabetes and their cardiovascular complications. Circ Res. 2016;118(11):1723-35. https://doi.org/10.1161/CIRCRESAHA. 115.306825 .

50. Miller WC, Koceja DM, Hamilton EJ. A meta-analysis of the past 25 years of weight loss research using diet, exercise or diet plus exercise intervention. Int J Obes Relat Metab Disord. 1997;21(10):941-7. https://doi.org/10.1038/sj.ijo.0800499.

51. McTigue KM, Harris R, Hemphill B, Lux L, Sutton S, Bunton AJ, Lohr KN. Screening and interventions for obesity in adults: summary of the evidence for the US Preventive Services Task Force. Ann Intern Med. 2003;139(11):933-49. https://doi.org/ 10.7326/0003-4819-139-11-200312020-00013.

52. Hansen D, Niebauer J, Cornelissen V, Barna O, Neunhäuserer D, Stettler C, Tonoli C, Greco E, Fagard R, Coninx K, Vanhees L, Piepoli MF, Pedretti R, Ruiz GR, Corrà U, Schmid JP, Davos CH, Edelmann F, Abreu A, Rauch B, Ambrosetti M, Braga SS, Beckers P, Bussotti M, Faggiano P, Garcia-Porrero E, Kouidi E, Lamotte M, Reibis R, Spruit MA, Takken T, Vigorito C, Völler H, Doherty P, Dendale P. Exercise prescription in patients with different combinations of cardiovascular disease risk factors: a consensus statement from the EXPERT Working Group. Sports Med. 2018;48(8):1781-97. https://doi.org/10. 1007/s40279-018-0930-4.

53. Mitchell NS, Catenacci VA, Wyatt HR, Hill JO. Obesity: overview of an epidemic. Psychiatr Clin North Am. 2011;34(4):71732. https://doi.org/10.1016/j.psc.2011.08.005.

54. Curioni CC, Lourenço PM. Long-term weight loss after diet and exercise: a systematic review. Int $\mathrm{J}$ Obes (Lond). 2005;29(10):1168-74. https://doi.org/10.1038/sj.ijo.0803015.

55. Thomas JG, Bond DS, Phelan S, Hill JO, Wing RR. Weight-loss maintenance for 10 years in the National Weight Control Registry. Am J Prev Med. 2014;46(1):17-23. https://doi.org/10.1016/j. amepre.2013.08.019.

56. Donnelly JE, Blair SN, Jakicic JM, Manore MM, Rankin JW, Smith BK, American College of Sports Medicine, American College of Sports Medicine Position Stand. Appropriate physical activity intervention strategies for weight loss and prevention of weight regain for adults. Med Sci Sports Exerc. 2009;41(2):45971. https://doi.org/10.1249/MSS.0b013e3181949333 (Erratum in: Med Sci Sports Exerc. 2009 Jul;41(7):1532).

57. Wood G, Taylor E, Ng V, Murrell A, Patil A, van der Touw T, Sigal R, Wolden M, Smart N. Determining the effect size of aerobic exercise training on the standard lipid profile in sedentary adults with three or more metabolic syndrome factors: a 
systematic review and meta-analysis of randomised controlled trials. Br J Sports Med. 2021. https://doi.org/10.1136/bjsports2021-103999 (Epub ahead of print).

58. Mazzone G, Morisco C, Lembo V, D’Argenio G, D'Armiento M, Rossi A, Giudice CD, Trimarco B, Caporaso N, Morisco F. Dietary supplementation of vitamin D prevents the development of western diet-induced metabolic, hepatic and cardiovascular abnormalities in rats. United Eur Gastroenterol J. 2018;6(7):1056-64. https://doi.org/10.1177/2050640618774140 (Epub 2018 May 17).

59. Katsagoni CN, Georgoulis M, Papatheodoridis GV, Panagiotakos DB, Kontogianni MD. Effects of lifestyle interventions on clinical characteristics of patients with non-alcoholic fatty liver disease: a meta-analysis. Metabolism. 2017;68:119-32. https:// doi.org/10.1016/j.metabol.2016.12.006 (Epub 2016 Dec 16).

60. Słomko J, Zalewska M, Niemiro W, Kujawski S, Słupski M, Januszko-Giergielewicz B, Zawadka-Kunikowska M, Newton J, Hodges L, Kubica J, Zalewski P. Evidence-based aerobic exercise training in metabolic-associated fatty liver disease: systematic review with meta-analysis. J Clin Med. 2021;10(8):1659. https:// doi.org/10.3390/jcm10081659.

61. King AC, Haskell WL, Young DR, Oka RK, Stefanick ML. Long-term effects of varying intensities and formats of physical activity on participation rates, fitness, and lipoproteins in men and women aged 50 to 65 years. Circulation. 1995;91(10):2596604. https://doi.org/10.1161/01.cir.91.10.2596.

62. Kodama S, Tanaka S, Saito K, Shu M, Sone Y, Onitake F, Suzuki E, Shimano H, Yamamoto S, Kondo K, Ohashi Y, Yamada N, Sone H. Effect of aerobic exercise training on serum levels of high-density lipoprotein cholesterol: a meta-analysis. Arch Intern Med. 2007;167(10):999-1008. https://doi.org/10.1001/archinte. 167.10.999.

63. Palatini P, Graniero GR, Mormino P, Nicolosi L, Mos L, Visentin $\mathrm{P}$, Pessina AC. Relation between physical training and ambulatory blood pressure in stage I hypertensive subjects. Results of the HARVEST Trial. Hypertension and Ambulatory Recording Venetia Study. Circulation. 1994;90(6):2870-6. https://doi.org/ 10.1161/01.cir.90.6.2870.

64. Cornelissen VA, Buys R, Smart NA. Endurance exercise beneficially affects ambulatory blood pressure: a systematic review and meta-analysis. J Hypertens. 2013;31(4):639-48. https://doi. org/10.1097/HJH.0b013e32835ca964.

65. Cornelissen VA, Smart NA. Exercise training for blood pressure: a systematic review and meta-analysis. J Am Heart Assoc. 2013;2(1): e004473. https://doi.org/10.1161/JAHA.112.004473.

66. Andersen LB, Schnohr P, Schroll M, Hein HO. All-cause mortality associated with physical activity during leisure time, work, sports, and cycling to work. Arch Intern Med. 2000;160(11):1621-8. https://doi.org/10.1001/archinte.160.11. 1621.

67. Arnett DK, Blumenthal RS, Albert MA, Buroker AB, Goldberger ZD, Hahn EJ, Himmelfarb CD, Khera A, Lloyd-Jones D, McEvoy JW, Michos ED, Miedema MD, Muñoz D, Smith SC Jr, Virani SS, Williams KA Sr, Yeboah J, Ziaeian B. 2019 ACC/aha guideline on the primary prevention of cardiovascular disease: a report of the American College of Cardiology/American Heart Association Task Force on clinical practice guidelines. Circulation. 2019;140(11):e596-646. https://doi.org/10.1161/CIR.00000 00000000678 (Epub 2019 Mar 17. Erratum in: Circulation. 2019 Sep 10;140(11):e649-e650. Erratum in: Circulation. 2020 Jan 28;141(4):e60. Erratum in: Circulation. 2020 Apr 21;141(16):e774).

68. McMahon SR, Ades PA, Thompson PD. The role of cardiac rehabilitation in patients with heart disease. Trends Cardiovasc Med. 2017;27(6):420-5. https://doi.org/10.1016/j.tcm.2017.02. 005 (Epub 2017 Feb 15).
69. Piepoli MF, Corrà U, Adamopoulos S, Benzer W, BjarnasonWehrens B, Cupples M, Dendale P, Doherty P, Gaita D, Höfer S, McGee H, Mendes M, Niebauer J, Pogosova N, Garcia-Porrero E, Rauch B, Schmid JP, Giannuzzi P. Secondary prevention in the clinical management of patients with cardiovascular diseases. Core components, standards and outcome measures for referral and delivery: a policy statement from the cardiac rehabilitation section of the European Association for Cardiovascular Prevention and Rehabilitation. Endorsed by the Committee for Practice Guidelines of the European Society of Cardiology. Eur J Prev Cardiol. 2014;21(6):664-81. https://doi.org/10.1177/20474 87312449597 (Epub 2012 Jun 20).

70. Cole JA, Smith SM, Hart N, Cupples ME. Systematic review of the effect of diet and exercise lifestyle interventions in the secondary prevention of coronary heart disease. Cardiol Res Pract. 2010;19(2011): 232351. https://doi.org/10.4061/2011/232351.

71. Trichopoulou A, Bamia C, Norat T, Overvad K, Schmidt EB, Tjønneland A, Halkjaer J, Clavel-Chapelon F, Vercambre MN, Boutron-Ruault MC, Linseisen J, Rohrmann S, Boeing H, Weikert C, Benetou V, Psaltopoulou T, Orfanos P, Boffetta P, Masala G, Pala V, Panico S, Tumino R, Sacerdote C, Buenode-Mesquita HB, Ocke MC, Peeters PH, Van der Schouw YT, González C, Sanchez MJ, Chirlaque MD, Moreno C, Larrañaga N, Van Guelpen B, Jansson JH, Bingham S, Khaw KT, Spencer EA, Key T, Riboli E, Trichopoulos D. Modified Mediterranean diet and survival after myocardial infarction: the EPIC-Elderly study. Eur J Epidemiol. 2007;22(12):871-81. https://doi.org/ 10.1007/s10654-007-9190-6 (Epub 2007 Oct 10).

72. Anderson L, Brown JP, Clark AM, Dalal H, Rossau HK, Bridges C, Taylor RS. Patient education in the management of coronary heart disease. Cochrane Database Syst Rev. 2017;6(6):CD008895. https://doi.org/10.1002/14651858. CD008895.pub3.

73. Pavy B, Barbet R, Carré F, Champion C, Iliou MC, Jourdain P, Juillière $\mathrm{Y}$, Monpère $\mathrm{C}$, Brion R, Working Group of Exercise Rehabilitation and Sport; Therapeutic Education Commission of the French Society of Cardiology. Therapeutic education in coronary heart disease: position paper from the Working Group of Exercise Rehabilitation and Sport (GERS) and the Therapeutic Education Commission of the French Society of Cardiology. Arch Cardiovasc Dis. 2013;106(12):680-9. https:// doi.org/10.1016/j.acvd.2013.10.002 (Epub 2013 Nov 15).

74. Richards SH, Anderson L, Jenkinson CE, Whalley B, Rees K, Davies P, Bennett P, Liu Z, West R, Thompson DR, Taylor RS. Psychological interventions for coronary heart disease: cochrane systematic review and meta-analysis. Eur J Prev Cardiol. 2018;25(3):247-59. https://doi.org/10.1177/2047487317 739978 (Epub 2017 Dec 7).

75. European Association of Cardiovascular Prevention and Rehabilitation Committee for Science Guidelines, EACPR, Corrà U, Piepoli MF, Carré F, Heuschmann P, Hoffmann U, Verschuren M, Halcox J, Document Reviewers, Giannuzzi P, Saner H, Wood D, Piepoli MF, Corrà U, Benzer W, Bjarnason-Wehrens B, Dendale P, Gaita D, McGee H, Mendes M, Niebauer J, Zwisler AD, Schmid JP. Secondary prevention through cardiac rehabilitation: physical activity counselling and exercise training: key components of the position paper from the Cardiac Rehabilitation Section of the European Association of Cardiovascular Prevention and Rehabilitation. Eur Heart J. 2010;31(16):1967-74. https://doi.org/10.1093/eurheartj/ ehq236 (Epub 2010 Jul 19).

76. Di Minno A, Gentile M, Iannuzzo G, Calcaterra I, Tripaldella M, Porro B, Cavalca V, Di Taranto MD, Tremoli E, Fortunato G, Rubba POF, Di Minno MND. Endothelial function improvement in patients with familial hypercholesterolemia receiving PCSK-9 inhibitors on top of maximally tolerated lipid lowering therapy. 
Thromb Res. 2020;194:229-36. https://doi.org/10.1016/j.throm res.2020.07.049 (Epub 2020 Jul 31).

77. Di Minno MND, Gentile M, Di Minno A, Iannuzzo G, Calcaterra I, Buonaiuto A, Di Taranto MD, Giacobbe C, Fortunato G, Rubba POF. Changes in carotid stiffness in patients with familial hypercholesterolemia treated with Evolocumab ${ }^{\circledR}$ : a prospective cohort study. Nutr Metab Cardiovasc Dis. 2020;30(6):996-1004. https://doi.org/10.1016/j.numecd.2020.02.018 (Epub 2020 Mar 6).

78. Giallauria F, Vitale G, Pacileo M, Di Lorenzo A, Oliviero A, Passaro F, Calce R, Parlato A, Testa C, D'Ambrosio G, Romano G, Clemenza F, Sarullo S, Venturini E, Gentile M, Nugara C, Iannuzzo G, D’Andrea A, Vigorito C, Sarullo FM. Sacubitril/ valsartan improves autonomic function and cardiopulmonary parameters in patients with heart failure with reduced ejection fraction. J Clin Med. 2020;9(6):1897. https://doi.org/10.3390/ jcm9061897.

79. Vitale G, Romano G, Di Franco A, et al. Early effects of sacubitril/valsartan on exercise tolerance in patients with heart failure with reduced ejection fraction. J Clin Med. 2019;8(2):E262. https://doi.org/10.3390/jcm8020262.

80. Buono F, Spinelli L, Giallauria F, Assante di Panzillo E, Di Marino S, Ferrara F, Vigorito C, Trimarco B, Morisco C. Usefulness of satisfactory control of low-density lipoprotein cholesterol to predict left ventricular remodeling after a first STelevation myocardial infarction successfully reperfused. Am J Cardiol. 2011;107(12):1772-8. https://doi.org/10.1016/j.amjca rd.2011.01.066 (Epub 2011 Apr 29).

81. Giallauria F, Vigorito C, Piepoli MF, Stewart Coats AJ. Effects of cardiac contractility modulation by non-excitatory electrical stimulation on exercise capacity and quality of life: an individual patient's data meta-analysis of randomized controlled trials. Int J Cardiol. 2014;175(2):352-7. https://doi.org/10. 1016/j.ijcard.2014.06.005 (Epub 2014 Jun 19).

82. Giallauria F, Cuomo G, Parlato A, Raval NY, Kuschyk J, Stewart Coats AJ. A comprehensive individual patient data meta-analysis of the effects of cardiac contractility modulation on functional capacity and heart failure-related quality of life. ESC Heart Fail. 2020;7(5):2922-32. https://doi.org/10.1002/ ehf2.12902.

83. Giallauria F, Parlato A, Di Lorenzo A, Testa C, D'Onofrio A, Sinagra G, Biffi M, Vigorito C, Coats AJS. Cardiac contractility modulation in patients with heart failure with reduced left ventricular ejection fraction. Hearts. 2021;2(1):156-69. https://doi. org/10.3390/hearts2010013.

84. Biffi M, Aspromonte N, Bongiorni MG, Clemenza F, D’Onofrio A, De Ferrari GM, Giallauria F, Grimaldi M, Oliva F, Senni M, Tondo C, Zecchin M, Cappannoli L, Giannotti Santoro M, Ziacchi M, Porcari A, Sinagra G. Modulazione della contrattilità cardiaca nello scompenso cardiaco a frazione di eiezione ridotta: revisione critica delle evidenze ed aspetti decisionali pratici [Cardiac contractility modulation in heart failure with reduced ejection fraction: critical review of evidence and application perspectives]. G Ital Cardiol Rome. 2021;22(9):727-41. https://doi.org/ $10.1714 / 3660.36450$ (Italian).

85. Giallauria F, Di Lorenzo A, Parlato A, Testa C, Bobbio E, Vigorito C, Coats AJS. Individual patient data meta-analysis of the effects of the CARILLON ${ }^{\circledR}$ mitral contour system. ESC Heart Fail. 2020;7(6):3383-91. https://doi.org/10.1002/ehf2.13125.

86. Cirillo P, Izzo R, Mancusi C, Buono F, Ziviello F, Spinelli L, Esposito G, Di Gioia G, Barbato E, Strisciuglio T, Trimarco B, Morisco C. Impact of drug-eluting stents on left ventricular wall motion after successful reperfusion of first anterior ST elevation myocardial infarction. Minerva Cardiol Angiol. 2021;69(2):14453. https://doi.org/10.23736/S0026-4725.20.05176-2 (Epub 2020 Jun 8 ).
87. Sperlongano S, D’Andrea A, Mele D, Russo V, Pergola V, Carbone A, Ilardi F, Di Maio M, Bottino R, Giallauria F, Bossone E, Golino P. Left ventricular deformation and vortex analysis in heart failure: from ultrasound technique to current clinical application. Diagnostics (Basel). 2021;11(5):892. https://doi.org/ 10.3390/diagnostics11050892.

88. D'Andrea A, Radmilovic J, Russo V, Sperlongano S, Carbone A, Di Maio M, Ilardi F, Riegler L, D’Alto M, Giallauria F, Bossone E, Picano E. Biventricular dysfunction and lung congestion in athletes on anabolic androgenic steroids: a speckle tracking and stress lung echocardiography analysis. Eur J Prev Cardiol. 2021. https://doi.org/10.1093/eurjpc/zwab086 (Epub ahead of print. PMID: 34339497).

89. D’Andrea A, Sperlongano S, Formisano T, Tocci G, Cameli M, Tusa M, Novo G, Corrado G, Ciampi Q, Citro R, Bossone E, Galderisi M, Giallauria F, Ambrosio G, Picano E. Stress Echocardiography and Strain in Aortic Regurgitation (SESAR protocol): left ventricular contractile reserve and myocardial work in asymptomatic patients with severe aortic regurgitation. Echocardiography. 2020;37(8):1213-21. https://doi.org/10.1111/echo. 14804 (Epub 2020 Aug 6).

90. D'Andrea A, Sperlongano S, Pacileo M, Venturini E, Iannuzzo G, Gentile M, Sperlongano R, Vitale G, Maglione M, Cice G, Maria Sarullo F, Di Lorenzo A, Vigorito C, Giallauria F, Picano E. New ultrasound technologies for ischemic heart disease assessment and monitoring in cardiac rehabilitation. J Clin Med. 2020;9(10):3131. https://doi.org/10.3390/jcm9103131.

91. Kotseva K, De Backer G, De Bacquer D, Rydén L, Hoes A, Grobbee D, Maggioni A, Marques-Vidal P, Jennings C, Abreu A, Aguiar C, Badariene J, Bruthans J, Castro Conde A, Cifkova R, Crowley J, Davletov K, Deckers J, De Smedt D, De Sutter J, Dilic M, Dolzhenko M, Dzerve V, Erglis A, Fras Z, Gaita D, Gotcheva N, Heuschmann P, Hasan-Ali H, Jankowski P, Lalic N, Lehto S, Lovic D, Mancas S, Mellbin L, Milicic D, Mirrakhimov E, Oganov R, Pogosova N, Reiner Z, Stöerk S, Tokgözoğlu L, Tsioufis C, Vulic D, Wood D, EUROASPIRE Investigators*. Lifestyle and impact on cardiovascular risk factor control in coronary patients across 27 countries: results from the European Society of Cardiology ESC-EORP EUROASPIRE V registry. Eur J Prev Cardiol. 2019;26(8):824-35. https://doi.org/10.1177/ 2047487318825350 (Epub 2019 Feb 10).

92. Gentile M, Iannuzzi A, Iannuzzo G, Covetti G, Panico S, Mattiello A, De Michele M, Rubba P. Relation of body mass index with carotid intima-media thickness and diameter is independent of metabolic syndrome in postmenopausal Mediterranean women. Menopause. 2012;19(10):1104-8. https://doi.org/10. 1097/gme.0b013e31825ad66c.

93. Gentile M, Iannuzzo G, Mattiello A, Rubba F, Panico S, Rubba $\mathrm{P}$. Association between body shape index and small dense LDL particles in a cohort of Mediterranean women: findings from Progetto ATENA. J Clin Biochem Nutr. 2017;61(2):130-4. https:// doi.org/10.3164/jcbn.17-13 (Epub 2017 Aug 11).

94. Anderson L, Thompson DR, Oldridge N, Zwisler AD, Rees K, Martin N, Taylor RS. Exercise-based cardiac rehabilitation for coronary heart disease. Cochrane Database Syst Rev. 2016;2016(1):CD001800. https://doi.org/10.1002/14651858. CD001800.pub3.

95. Smart NA, Waldron M, Ismail H, Giallauria F, Vigorito C, Cornelissen V, Dieberg G. Validation of a new tool for the assessment of study quality and reporting in exercise training studies: TESTEX. Int J Evid Based Healthc. 2015;13(1):9-18. https:// doi.org/10.1097/XEB.0000000000000020.

96. Faggiano P, Fattirolli F, Frisinghelli A, Piccioli L, Dasseni N, Silverii MV, Albricci L, D’Ambrosio G, Garrì R, Esposito L, Giallauria F. Secondary prevention advices after cardiovascular index event: from drug prescription to risk factors control in real 
world practice. Monaldi Arch Chest Dis. 2019. https://doi.org/ 10.4081/monaldi.2019.1040.

97. Fattirolli F, Argirò A, Angelino ME, Balestroni G, Giallauria F, Miani D, Vigorito C, Piccioli L, Genta FT, Höfer S, Marchionni N, Oldridge N. Validation of the Italian HeartQoL: a short health-related quality of life questionnaire for patients with ischemic heart disease. Intern Emerg Med. 2021. https://doi.org/ 10.1007/s11739-021-02780-2 (Epub ahead of print).

98. Testa C, Di Lorenzo A, Parlato A, D’Ambrosio G, Merolla A, Pacileo M, Iannuzzo G, Gentile M, Nugara C, Sarullo FM, De Gregorio C, D'Andrea A, Vigorito C, Venturini E, Giallauria F. Exercise for slowing the progression of atherosclerotic process: effects on inflammatory markers. Panminerva Med. 2021;63(2):122-32. https://doi.org/10.23736/S0031-0808.21. 04266-X (Epub 2021 Feb 10).

99. Sutton MG, Sharpe N. Left ventricular remodeling after myocardial infarction: pathophysiology and therapy. Circulation. 2000;101(25):2981-8. https://doi.org/10.1161/01.cir.101.25. 2981.

100. Giallauria F, Cirillo P, Lucci R, Pacileo M, De Lorenzo A, D’Agostino M, Moschella S, Psaroudaki M, Del Forno D, Orio F, Vitale DF, Chiariello M, Vigorito C. Left ventricular remodelling in patients with moderate systolic dysfunction after myocardial infarction: favourable effects of exercise training and predictive role of N-terminal pro-brain natriuretic peptide. Eur J Cardiovasc Prev Rehabil. 2008;15(1):113-8. https://doi.org/10.1097/HJR. 0b013e3282f00990.

101. Giallauria F, Lucci R, De Lorenzo A, D’Agostino M, Del Forno D, Vigorito C. Favourable effects of exercise training on N-terminal pro-brain natriuretic peptide plasma levels in elderly patients after acute myocardial infarction. Age Ageing. 2006;35(6):6017. https://doi.org/10.1093/ageing/afl098 (Epub 2006 Sep 1).

102. Kinnunen P, Vuolteenaho O, Ruskoaho H. Mechanisms of atrial and brain natriuretic peptide release from rat ventricular myocardium: effect of stretching. Endocrinology. 1993;132(5):1961-70. https://doi.org/10.1210/endo.132.5.8477647.

103. Smart NA, Meyer T, Butterfield JA, Faddy SC, Passino C, Malfatto G, Jonsdottir S, Sarullo F, Wisloff U, Vigorito C, Giallauria F. Individual patient meta-analysis of exercise training effects on systemic brain natriuretic peptide expression in heart failure. Eur J Prev Cardiol. 2012;19(3):428-35. https://doi.org/10.1177/ 1741826711409171 (Epub 2011 May 4).

104. Oremus M, Raina PS, Santaguida P, Balion CM, McQueen MJ, McKelvie R, Worster A, Booker L, Hill SA. A systematic review of BNP as a predictor of prognosis in persons with coronary artery disease. Clin Biochem. 2008;41(4-5):260-5. https://doi. org/10.1016/j.clinbiochem.2007.09.011 (Epub 2007 Sep 25).

105. Niccoli G, Conte M, Marchitti S, Montone RA, Fracassi F, Grippo R, Roberto M, Burzotta F, Trani C, Leone AM, Bianchi F, Di Castro S, Volpe M, Crea F, Rubattu S. NT-proANP and NTproBNP circulating levels as predictors of cardiovascular outcome following coronary stent implantation. Cardiovasc Revasc Med. 2016;17(3):162-8. https://doi.org/10.1016/j.carrev.2016. 02.012 (Epub 2016 Feb 27).

106. Benjamin EJ, D’Agostino RB, Belanger AJ, Wolf PA, Levy D. Left atrial size and the risk of stroke and death. The Framingham Heart Study. Circulation. 1995;92(4):835-41. https://doi.org/10. 1161/01.cir.92.4.835.

107. Moller JE, Hillis GS, Oh JK, et al. Left atrial volume: a powerful predictor of survival after acute myocardial infarction. Circulation. 2003;107(17):2207-12. https://doi.org/10.1161/01.CIR. 0000066318.21784 .43 .

108. Giallauria F, Galizia G, Lucci R, D’Agostino M, Vitelli A, Maresca L, Orio F, Vigorito C. Favourable effects of exercisebased cardiac rehabilitation after acute myocardial infarction on left atrial remodeling. Int J Cardiol. 2009;136(3):300-6. https:// doi.org/10.1016/j.ijcard.2008.05.026 (Epub 2008 Aug 3).

109. Mann DL, Kent RL, Parsons B, Cooper G 4th. Adrenergic effects on the biology of the adult mammalian cardiocyte. Circulation. 1992;85(2):790-804. https://doi.org/10.1161/01.cir.85.2.790.

110. Braith RW, Edwards DG. Neurohormonal abnormalities in heart failure: impact of exercise training. Congest Heart Fail. 2003;9(2):70-6. https://doi.org/10.1111/j.1527-5299.2003. 00277.x.

111. Shan K, Bick RJ, Poindexter BJ, Nagueh SF, Shimoni S, Verani MS, Keng F, Reardon MJ, Letsou GV, Howell JF, Zoghbi WA. Altered adrenergic receptor density in myocardial hibernation in humans: a possible mechanism of depressed myocardial function. Circulation. 2000;102(21):2599-606. https://doi.org/10.1161/01. cir.102.21.2599.

112. Giallauria F, Del Forno D, Pilerci F, De Lorenzo A, Manakos A, Lucci R, Vigorito C. Improvement of heart rate recovery after exercise training in older people. J Am Geriatr Soc. 2005;53(11):2037-8. https://doi.org/10.1111/j.1532-5415.2005. 00479_4.x.

113. Giallauria F, Lucci R, Pietrosante M, Gargiulo G, De Lorenzo A, D’Agostino M, Gerundo G, Abete P, Rengo F, Vigorito C. Exercise-based cardiac rehabilitation improves heart rate recovery in elderly patients after acute myocardial infarction. J Gerontol A Biol Sci Med Sci. 2006;61(7):713-7. https://doi. org/10.1093/gerona/61.7.713.

114. Giallauria F, De Lorenzo A, Pilerci F, Manakos A, Lucci R, Psaroudaki M, D’Agostino M, Del Forno D, Vigorito C. Longterm effects of cardiac rehabilitation on end-exercise heart rate recovery after myocardial infarction. Eur J Cardiovasc Prev Rehabil. 2006;13(4):544-50. https://doi.org/10.1097/01.hjr. 0000216547.07432.fb.

115. Cole CR, Blackstone EH, Pashkow FJ, Snader CE, Lauer MS Heart-rate recovery immediately after exercise as a predictor of mortality. N Engl J Med. 1999;341(18):1351-7. https://doi. org/10.1056/NEJM199910283411804.

116. Watanabe J, Thamilarasan M, Blackstone EH, Thomas JD, Lauer MS. Heart rate recovery immediately after treadmill exercise and left ventricular systolic dysfunction as predictors of mortality: the case of stress echocardiography. Circulation. 2001;104(16):1911-6.

117. Malfatto G, Facchini M, Sala L, Branzi G, Bragato R, Leonetti G. Relationship between baseline sympatho-vagal balance and the autonomic response to cardiac rehabilitation after a first uncomplicated myocardial infarction. Ital Heart J. 2000;1(3):226-32.

118. Watanabe AM, McConnaughey MM, Strawbridge RA, Fleming JW, Jones LR, Besch HR Jr. Muscarinic cholinergic receptor modulation of beta-adrenergic receptor affinity for catecholamines. J Biol Chem. 1978;253(14):4833-6.

119. Casado MA, Sevilla MA, Alonso MJ, Marin J, Salaices M. Muscarinic receptors involved in modulation of norepinephrine release and vasodilatation in guinea pig carotid arteries. J Pharmacol Exp Ther. 1994;271(3):1638-46.

120. Cirillo P, Giallauria F, Pacileo M, Petrillo G, D’Agostino M, Vigorito C, Chiariello M. Increased high mobility group box-1 protein levels are associated with impaired cardiopulmonary and echocardiographic findings after acute myocardial infarction. J Card Fail. 2009;15(4):362-7. https://doi.org/10.1016/j.cardfail. 2008.11.010 (Epub 2009 Jan 9).

121. Giallauria F, Cirillo P, Lucci R, Pacileo M, D'agostino M, Maietta P, Vitelli A, Chiariello M, Vigorito C. Effects of exercisebased cardiac rehabilitation on high mobility group box-1 levels after acute myocardial infarction: rationale and design. J Cardiovasc Med (Hagerstown). 2009;10(8):659-63. https://doi.org/10. 2459/JCM.0b013e32832d4979. 
122. Giallauria F, Cirillo P, Lucci R, Pacileo M, D'Agostino M, Maietta P, Vitelli A, Chiariello M, Vigorito C. Autonomic dysfunction is associated with high mobility group box-1 levels in patients after acute myocardial infarction. Atherosclerosis. 2010;208(1):280-4. https://doi.org/10.1016/j.atherosclerosis. 2009.07.025 (Epub 2009 Jul 14).

123. Giallauria F, Cirillo P, D'agostino M, Petrillo G, Vitelli A, Pacileo M, Angri V, Chiariello M, Vigorito C. Effects of exercise training on high-mobility group box-1 levels after acute myocardial infarction. J Card Fail. 2011;17(2):108-14. https://doi.org/ 10.1016/j.cardfail.2010.09.001 (Epub 2010 Oct 29).

124. Cirillo P, Giallauria F, Di Palma V, Maresca F, Ziviello F, Bevilacqua M, Vigorito C, Trimarco B. Cardiovascular disease and high-mobility group box 1-is a new inflammatory killer in town? Angiology. 2013;64(5):343-55. https://doi.org/10.1177/00033 19712458032 (Epub 2012 Aug 31).

125. Scaffidi P, Misteli T, Bianchi ME. Release of chromatin protein HMGB 1 by necrotic cells triggers inflammation. Nature. 2002;418(6894):191-5. https://doi.org/10.1038/nature00858. Erratum.In:Nature.2010Sep30;467(7315):622.

126. Tzeng HP, Fan J, Vallejo JG, Dong JW, Chen X, Houser SR, Mann DL. Negative inotropic effects of high-mobility group box 1 protein in isolated contracting cardiac myocytes. Am $\mathbf{J}$ Physiol Heart Circ Physiol. 2008;294(3):H1490-6. https://doi. org/10.1152/ajpheart.00910.2007 (Epub 2008 Jan 25).

127. Ito T, Kawahara K, Nakamura T, Yamada S, Nakamura T, Abeyama K, Hashiguchi T, Maruyama I. High-mobility group box 1 protein promotes development of microvascular thrombosis in rats. J Thromb Haemost. 2007;5(1):109-16. https://doi.org/10. 1111/j.1538-7836.2006.02255.x.

128. Kohno T, Anzai T, Naito K, Miyasho T, Okamoto M, Yokota H, Yamada S, Maekawa Y, Takahashi T, Yoshikawa T, Ishizaka A, Ogawa $S$. Role of high-mobility group box 1 protein in postinfarction healing process and left ventricular remodelling. Cardiovasc Res. 2009;81(3):565-73. https://doi.org/10.1093/cvr/ cvn291 (Epub 2008 Nov 3).

129. Rengo G, Parisi V, Femminella GD, Pagano G, de Lucia C, Cannavo A, Liccardo D, Giallauria F, Scala O, Zincarelli C, Perrone Filardi P, Ferrara N, Leosco D. Molecular aspects of the cardioprotective effect of exercise in the elderly. Aging Clin Exp Res. 2013;25(5):487-97. https://doi.org/10.1007/s40520-013-0117-7 (Epub 2013 Aug 15).

130. Vigorito C, Giallauria F. Effects of exercise on cardiovascular performance in the elderly. Front Physiol. 2014;20(5):51. https:// doi.org/10.3389/fphys.2014.00051.

131. Parker L, Trewin A, Levinger I, Shaw CS, Stepto NK. Exerciseintensity dependent alterations in plasma redox status do not reflect skeletal muscle redox-sensitive protein signaling. J Sci Med Sport. 2018;21(4):416-21. https://doi.org/10.1016/j.jsams. 2017.06.017 (Epub 2017 Jul 1).

132. Cerqueira-Gomes M, Maciel MJ, de Faria DB. Endothelium disfunction in coronary artery disease. Rev Port Cardiol. 1992;11(10):873-86.

133. Pompilio G, Rossoni G, Alamanni F, Tartara P, Barajon I, Rumio C, Manfredi B, Biglioli P. Comparison of endothelium-dependent vasoactivity of internal mammary arteries from hypertensive, hypercholesterolemic, and diabetic patients. Ann Thorac Surg. 2001;72(4):1290-7. https://doi.org/10.1016/s0003-4975(01) 03053-3.

134. Hambrecht R, Adams V, Erbs S, Linke A, Kränkel N, Shu Y, Baither Y, Gielen S, Thiele H, Gummert JF, Mohr FW, Schuler G. Regular physical activity improves endothelial function in patients with coronary artery disease by increasing phosphorylation of endothelial nitric oxide synthase. Circulation. 2003;107(25):3152-8. https://doi.org/10.1161/01.CIR.00000 74229.93804.5C (Epub 2003 Jun 16).
135. Tarro Genta F, Eleuteri E, Temporelli PL, Comazzi F, Tidu M, Bouslenko Z, Bertolin F, Vigorito C, Giannuzzi P, Giallauria F. Flow-mediated dilation normalization predicts outcome in chronic heart failure patients. J Card Fail. 2013;19(4):260-7. https://doi.org/10.1016/j.cardfail.2013.01.014 (Epub 2013 Mar 19).

136. Giallauria F, Acampa W, Ricci F, Vitelli A, Maresca L, Mancini M, Grieco A, Gallicchio R, Xhoxhi E, Spinelli L, Cuocolo A, Vigorito C. Effects of exercise training started within 2 weeks after acute myocardial infarction on myocardial perfusion and left ventricular function: a gated SPECT imaging study. Eur J Prev Cardiol. 2012;19(6):1410-9. https://doi.org/10.1177/17418 26711425427 (Epub 2011 Sep 30).

137. Giallauria F, Acampa W, Ricci F, Vitelli A, Torella G, Lucci R, Del Prete G, Zampella E, Assante R, Rengo G, Leosco D, Cuocolo A, Vigorito C. Exercise training early after acute myocardial infarction reduces stress-induced hypoperfusion and improves left ventricular function. Eur J Nucl Med Mol Imaging. 2013;40(3):315-24. https://doi.org/10.1007/s00259-012-2302-x (Epub 2012 Dec 6).

138. Smart NA, Dieberg G, Giallauria F. Intermittent versus continuous exercise training in chronic heart failure: a meta-analysis. Int J Cardiol. 2013;166(2):352-8. https://doi.org/10.1016/j.ijcard. 2011.10.075 (Epub 2011 Nov 17).

139. Smart NA, Dieberg G, Giallauria F. Functional electrical stimulation for chronic heart failure: a meta-analysis. Int J Cardiol. 2013;167(1):80-6. https://doi.org/10.1016/j.ijcard.2011.12.019 (Epub 2012 Jan 10).

140. Smart NA, Giallauria F, Dieberg G. Efficacy of inspiratory muscle training in chronic heart failure patients: a systematic review and meta-analysis. Int J Cardiol. 2013;167(4):1502-7. https:// doi.org/10.1016/j.ijcard.2012.04.029 (Epub 2012 May 3).

141. Dieberg G, Ismail H, Giallauria F, Smart NA. Clinical outcomes and cardiovascular responses to exercise training in heart failure patients with preserved ejection fraction: a systematic review and meta-analysis. J Appl Physiol (1985). 2015;119(6):726-33. https://doi.org/10.1152/japplphysiol.00904.2014 (Epub 2015 Mar 6).

142. Sirico D, Salzano A, Celentani D, Arcopinto M, Marra AM, Bobbio E, Russo A, Giallauria F, Vigorito C. Terapie antiremodeling: nuove strategie e prospettive future nell'insufficienza cardiaca cronica post ischemica: Parte I [Anti remodeling therapy: new strategies and future perspective in post-ischemic heart failure: Part I]. Monaldi Arch Chest Dis. 2014;82(4):187-94. https://doi. org/10.4081/monaldi.2014.63 (Italian).

143. Salzano A, Sirico D, Arcopinto M, Marra AM, Guerra G, Rocca A, Grieco A, Giallauria F, Vigorito C. Terapie antiremodeling: nuove strategie e prospettive future nell'insufficienza cardiaca cronica post ischemica: Parte II [Anti remodeling therapy: new strategies and future perspective in post-ischemic heart failure. Part II]. Monaldi Arch Chest Dis. 2014;82(4):195-201. https:// doi.org/10.4081/monaldi.2014.64 (Italian).

144. Giallauria F, Cittadini A, Smart NA, Vigorito C. Resistance training and sarcopenia. Monaldi Arch Chest Dis. 2016;84(1-2):738. https://doi.org/10.4081/monaldi.2015.738.

145. Giallauria F, Smart NA, Cittadini A, Vigorito C. Exercise training modalities in chronic heart failure: does high intensity aerobic interval training make the difference? Monaldi Arch Chest Dis. 2016;86(1-2):754. https://doi.org/10.4081/monaldi.2016. 754.

146. Chan E, Giallauria F, Vigorito C, Smart NA. Exercise training in heart failure patients with preserved ejection fraction: a systematic review and meta-analysis. Monaldi Arch Chest Dis. 2016;86(1-2):759. https://doi.org/10.4081/monaldi.2016.759.

147. Giallauria F, Piccioli L, Vitale G, Sarullo FM. Exercise training in patients with chronic heart failure: a new challenge for 
Cardiac Rehabilitation Community. Monaldi Arch Chest Dis. 2018;88(3):987. https://doi.org/10.4081/monaldi.2018.987.

148. Piepoli MF, Conraads V, Corrà U, Dickstein K, Francis DP, Jaarsma T, McMurray J, Pieske B, Piotrowicz E, Schmid JP, Anker SD, Solal AC, Filippatos GS, Hoes AW, Gielen S, Giannuzzi P, Ponikowski PP. Exercise training in heart failure: from theory to practice A consensus document of the Heart Failure Association and the European Association for Cardiovascular Prevention and Rehabilitation. Eur J Heart Fail. 2011;13(4):34757. https://doi.org/10.1093/eurjhf/hfr017.

149. Ferrucci L, Giallauria F, Guralnik JM. Epidemiology of aging. Radiol Clin North Am. 2008;46(4):643-52. https://doi.org/10. 1016/j.rcl.2008.07.005.

150. Ferrucci L, Giallauria F, Schlessinger D. Mapping the road to resilience: novel math for the study of frailty. Mech Ageing Dev. 2008;129(11):677-9. https://doi.org/10.1016/j.mad.2008.09.007 (Epub 2008 Sep 25).

151. Giallauria F, Vigorito C, Tramarin R, Fattirolli F, Ambrosetti M, De Feo S, Griffo R, Riccio C, Piepoli M, ISYDE-2008 Investigators of the Italian Association for Cardiovascular Prevention, Rehabilitation, and Prevention. Cardiac rehabilitation in very old patients: data from the Italian Survey on Cardiac Rehabilitation-2008 (ISYDE-2008)—official report of the Italian Association for Cardiovascular Prevention, Rehabilitation, and Epidemiology. J Gerontol A Biol Sci Med Sci. 2010;65(12):1353-61. https://doi.org/10.1093/gerona/glq138 (Epub 2010 Jul 28).

152. Vigorito $\mathrm{C}$, Abreu A, Ambrosetti M, Belardinelli R, Corrà U, Cupples M, Davos CH, Hoefer S, Iliou MC, Schmid JP, Voeller H, Doherty P. Frailty and cardiac rehabilitation: a call to action from the EAPC Cardiac Rehabilitation Section. Eur J Prev Cardiol. 2017;24(6):577-90. https://doi.org/10.1177/2047487316 682579 (Epub 2016 Dec 11).

153. Marinus N, Vigorito C, Giallauria F, Haenen L, Jansegers T, Dendale P, Feys P, Meesen R, Timmermans A, Spildooren J, Hansen D. Frailty is highly prevalent in specific cardiovascular diseases and females, but significantly worsens prognosis in all affected patients: a systematic review. Ageing Res Rev. 2021;66: 101233. https://doi.org/10.1016/j.arr.2020.101233 (Epub 2020 Dec 14).

154. Giallauria F, Di Lorenzo A, Venturini E, Pacileo M, D'Andrea A, Garofalo U, De Lucia F, Testa C, Cuomo G, Iannuzzo G, Gentile M, Nugara C, Sarullo FM, Marinus N, Hansen D, Vigorito C. Frailty in acute and chronic coronary syndrome patients entering cardiac rehabilitation. J Clin Med. 2021;10(8):1696. https://doi. org/10.3390/jcm10081696.

155. Lee JY, Ahn JM, Park DW, Kang SJ, Kim YH, Lee SW, Lee CW, Park SW, Park SJ. Impact of exercise-based cardiac rehabilitation on long-term clinical outcomes in patients with left main coronary artery stenosis. Eur J Prev Cardiol. 2016;23(17):1804-13. https://doi.org/10.1177/2047487316658570 (Epub 2016 Jul 1).

156. Norris CM, Jensen LA, Galbraith PD, Graham MM, Daub WD, Knudtson ML, Ghali WA. Referral rate and outcomes of cardiac rehabilitation after cardiac catheterization in a large Canadian city. J Cardiopulm Rehabil. 2004;24(6):392-400. https://doi.org/ 10.1097/00008483-200411000-00006.

157. Vanhees L, Rauch B, Piepoli M, van Buuren F, Takken T, Börjesson M, Bjarnason-Wehrens B, Doherty P, Dugmore D, Halle $\mathrm{M}$, Writing Group, EACPR. Importance of characteristics and modalities of physical activity and exercise in the management of cardiovascular health in individuals with cardiovascular disease (Part III). Eur J Prev Cardiol. 2012;19(6):1333-56. https://doi. org/10.1177/2047487312437063.

158. Trachsel LD, David LP, Gayda M, Henri C, Hayami D, ThorinTrescases N, Thorin É, Blain MA, Cossette M, Lalongé J, Juneau $\mathrm{M}$, Nigam A. The impact of high-intensity interval training on ventricular remodeling in patients with a recent acute myocardial infarction - a randomized training intervention pilot study. Clin Cardiol. 2019;42(12):1222-31. https://doi.org/10.1002/clc.23277 (Epub 2019 Oct 10).

159. Conraads VM, Pattyn N, De Maeyer C, et al. Aerobic interval training and continuous training equally improve aerobic exercise capacity in patients with coronary artery disease: the SAINTEXCAD study. Int J Cardiol. 2015;179:203-10. https://doi.org/10. 1016/j.ijcard.2014.10.155.

160. Wewege MA, Ahn D, Yu J, Liou K, Keech A. High-intensity interval training for patients with cardiovascular disease-is it safe? A systematic review. J Am Heart Assoc. 2018;7(21): e009305. https://doi.org/10.1161/JAHA.118.009305.

161. Fletcher GF, Ades PA, Kligfield P, et al. Exercise standards for testing and training: a scientific statement from the American Heart Association. Circulation. 2013;128(8):873-934. https:// doi.org/10.1161/CIR.0b013e31829b5b44.

162. Daub WD, Knapik GP, Black WR. Strength training early after myocardial infarction. J Cardiopulm Rehabil. 1996;16(2):100-8. https://doi.org/10.1097/00008483-199603000-00004.

163. Marzolini S, Oh PI, Brooks D. Effect of combined aerobic and resistance training versus aerobic training alone in individuals with coronary artery disease: a meta-analysis. Eur J Prev Cardiol. 2012;19(1):81-94. https://doi.org/10.1177/1741826710393197 (Epub 2011 Feb 21).

164. Yamamoto S, Hotta K, Ota E, Mori R, Matsunaga A. Effects of resistance training on muscle strength, exercise capacity, and mobility in middle-aged and elderly patients with coronary artery disease: a meta-analysis. J Cardiol. 2016;68(2):125-34. https:// doi.org/10.1016/j.jjcc.2015.09.005 (Epub 2015 Dec 12).

165. Rauch B, Davos CH, Doherty P, Saure D, Metzendorf MI, Salzwedel A, Völler H, Jensen K, Schmid JP, 'Cardiac Rehabilitation Section', European Association of Preventive Cardiology (EAPC), in cooperation with the Institute of Medical Biometry and Informatics (IMBI), Department of Medical Biometry, University of Heidelberg, and the Cochrane Metabolic and Endocrine Disorders Group, Institute of General Practice, HeinrichHeine University, Düsseldorf, Germany. The prognostic effect of cardiac rehabilitation in the era of acute revascularisation and statin therapy: a systematic review and meta-analysis of randomized and non-randomized studies - the Cardiac Rehabilitation Outcome Study (CROS). Eur J Prev Cardiol. 2016;23(18):1914 39. https://doi.org/10.1177/2047487316671181 (Epub 2016 Oct 25).

166. Salzwedel A, Jensen K, Rauch B, Doherty P, Metzendorf MI, Hackbusch M, Völler H, Schmid JP, Davos CH. Effectiveness of comprehensive cardiac rehabilitation in coronary artery disease patients treated according to contemporary evidence based medicine: update of the Cardiac Rehabilitation Outcome Study (CROS-II). Eur J Prev Cardiol. 2020;27(16):1756-74. https:// doi.org/10.1177/2047487320905719 (Epub 2020 Feb 23).

167. Maessen MF, Eijsvogels TM, Stevens G, van Dijk AP, Hopman MT. Benefits of lifelong exercise training on left ventricular function after myocardial infarction. Eur J Prev Cardiol. 2017;24(17):1856-66. https://doi.org/10.1177/2047487317 728765 (Epub 2017 Sep 1).

168. Orio F, Giallauria F, Palomba S, Manguso F, Orio M, Tafuri D, Lombardi G, Carmina E, Colao A, Vigorito C. Metabolic and cardiopulmonary effects of detraining after a structured exercise training programme in young PCOS women. Clin Endocrinol (Oxf). 2008;68(6):976-81. https://doi.org/10.1111/j.1365-2265. 2007.03117.x (Epub 2007 Nov 2).

169. Giallauria F, Orio F, Palomba S, Lombardi G, Colao A, Vigorito C. Cardiovascular risk in women with polycystic ovary syndrome. J Cardiovasc Med (Hagerstown). 2008;9(10):987-92. https://doi.org/10.2459/JCM.0b013e32830b58d4. 
170. Orio F Jr, Palomba S, Giallauria F, Colao A, Vigorito C. Impaired cardiopulmonary parameters in young women with polycystic ovary syndrome. Clin Endocrinol (Oxf). 2007;66(1):152-3. https://doi.org/10.1111/j.1365-2265.2006.02699.x.

171. Vigorito C, Giallauria F, Palomba S, Cascella T, Manguso F, Lucci R, De Lorenzo A, Tafuri D, Lombardi G, Colao A, Orio F. Beneficial effects of a three-month structured exercise training program on cardiopulmonary functional capacity in young women with polycystic ovary syndrome. J Clin Endocrinol Metab. 2007;92(4):1379-84. https://doi.org/10.1210/jc.20062794 (Epub 2007 Jan 30).

172. Giallauria F, Palomba S, Manguso F, Vitelli A, Maresca L, Tafuri D, Lombardi G, Colao A, Vigorito C, Orio F. Abnormal heart rate recovery after maximal cardiopulmonary exercise stress testing in young overweight women with polycystic ovary syndrome. Clin Endocrinol (Oxf). 2008;68(1):88-93. https://doi.org/10. 1111/j.1365-2265.2007.03004.x (Epub 2007 Sep 4).

173. Giallauria F, Palomba S, Maresca L, Vuolo L, Tafuri D, Lombardi G, Colao A, Vigorito C, Francesco O. Exercise training improves autonomic function and inflammatory pattern in women with polycystic ovary syndrome (PCOS). Clin Endocrinol (Oxf). 2008;69(5):792-8. https://doi.org/10.1111/j.13652265.2008.03305.x (Epub 2008 May 23).

174. Giallauria F, Palomba S, De Sio I, Maresca L, Vuolo L, Savastano S, Lombardi G, Colao A, Vigorito C, Orio F. Inflammatory markers and visceral fat are inversely associated with maximal oxygen consumption in women with polycystic ovary syndrome (PCOS). Clin Endocrinol (Oxf). 2009;70(3):394-400. https://doi. org/10.1111/j.1365-2265.2008.03336.x (Epub 2008 Jun 27).

175. Palomba S, Falbo A, Giallauria F, Russo T, Rocca M, Tolino A, Zullo F, Orio F. Six weeks of structured exercise training and hypocaloric diet increases the probability of ovulation after clomiphene citrate in overweight and obese patients with polycystic ovary syndrome: a randomized controlled trial. Hum Reprod. 2010;25(11):2783-91. https://doi.org/10.1093/humrep/deq254 (Epub 2010 Sep 21).

176. Giannuzzi P, Temporelli PL, Maggioni AP, Ceci V, Chieffo C, Gattone M, Griffo R, Marchioli R, Schweiger C, Tavazzi L, Urbinati S, Valagussa F, GOSPEL. GlObal Secondary Prevention strategiEs to limit event recurrence after myocardial infarction: the GOSPEL study A trial from the Italian Cardiac Rehabilitation Network: rationale and design. Eur J Cardiovasc Prev Rehabil. 2005;12(6):555-61. https://doi.org/10.1097/01.hjr.0000186623. 60486.26.

177. Giannuzzi P, Temporelli PL, Marchioli R, et al. Global secondary prevention strategies to limit event recurrence after myocardial infarction: results of the GOSPEL study, a multicenter, randomized controlled trial from the Italian Cardiac Rehabilitation Network. Arch Intern Med. 2008;168(20):2194-204. https://doi. org/10.1001/archinte.168.20.2194.

178. Giallauria F, Lucci R, D’Agostino M, Vitelli A, Maresca L, Mancini M, Aurino M, Del Forno D, Giannuzzi P, Vigorito C. Two-year multicomprehensive secondary prevention program: favorable effects on cardiovascular functional capacity and coronary risk profile after acute myocardial infarction. J Cardiovasc Med (Hagerstown). 2009;10(10):772-80. https://doi.org/10. 2459/JCM.0b013e32832d55fe.

179. Yue L, Feng J, Gaspo R, Li GR, Wang Z, Nattel S. Ionic remodeling underlying action potential changes in a canine model of atrial fibrillation. Circ Res. 1997;81(4):512-25. https://doi.org/ 10.1161/01.res.81.4.512.

180. Lampert R, Joska T, Burg MM, Batsford WP, McPherson CA, Jain D. Emotional and physical precipitants of ventricular arrhythmia. Circulation. 2002;106(14):1800-5. https://doi.org/ 10.1161/01.cir.0000031733.51374.c1.
181. Heidbüchel H, Hoogsteen J, Fagard R, Vanhees L, Ector H, Willems R, Van Lierde J. High prevalence of right ventricular involvement in endurance athletes with ventricular arrhythmias. Role of an electrophysiologic study in risk stratification. Eur Heart J. 2003;24(16):1473-80. https://doi.org/10.1016/s0195668x(03)00282-3.

182. Morganroth J, Maron BJ, Henry WL, Epstein SE. Comparative left ventricular dimensions in trained athletes. Ann Intern Med. 1975;82(4):521-4. https://doi.org/10.7326/0003-4819-82-4-521.

183. Stirbys P. How much exercise is too much. J Atr Fibrillation. 2013;5(5):819. https://doi.org/10.4022/jafib.819.

184. Andersen K, Farahmand B, Ahlbom A, Held C, Ljunghall S, Michaëlsson K, Sundström J. Risk of arrhythmias in 52755 long-distance cross-country skiers: a cohort study. Eur Heart J. 2013;34(47):3624-31. https://doi.org/10.1093/eurheartj/eht188 (Epub 2013 Jun 11).

185. Heidbüchel H, Anné W, Willems R, Adriaenssens B, Van de Werf $\mathrm{F}$, Ector $\mathrm{H}$. Endurance sports is a risk factor for atrial fibrillation after ablation for atrial flutter. Int J Cardiol. 2006;107(1):67-72. https://doi.org/10.1016/j.ijcard.2005.02.043.

186. Elosua R, Arquer A, Mont L, Sambola A, Molina L, GarcíaMorán E, Brugada J, Marrugat J. Sport practice and the risk of lone atrial fibrillation: a case-control study. Int J Cardiol. 2006;108(3):332-7. https://doi.org/10.1016/j.ijcard.2005.05. 020 (Epub 2005 Jun 16 Erratum in: Int J Cardiol. 2007 Dec 15;123(1):74).

187. Molina L, Mont L, Marrugat J, Berruezo A, Brugada J, Bruguera J, Rebato C, Elosua R. Long-term endurance sport practice increases the incidence of lone atrial fibrillation in men: a followup study. Europace. 2008;10(5):618-23. https://doi.org/10.1093/ europace/eun071 (Epub 2008 Apr 4).

188. Pelliccia A, Maron BJ, Di Paolo FM, Biffi A, Quattrini FM, Pisicchio C, Roselli A, Caselli S, Culasso F. Prevalence and clinical significance of left atrial remodeling in competitive athletes. J Am Coll Cardiol. 2005;46(4):690-6. https://doi.org/10.1016/j. jacc.2005.04.052.

189. Coote JH, White MJ. CrossTalk proposal: bradycardia in the trained athlete is attributable to high vagal tone. J Physiol. 2015;593(8):1745-7. https://doi.org/10.1113/jphysiol.2014. 284364.

190. Guasch E, Benito B, Qi X, Cifelli C, Naud P, Shi Y, Mighiu A, Tardif JC, Tadevosyan A, Chen Y, Gillis MA, Iwasaki YK, Dobrev D, Mont L, Heximer S, Nattel S. Atrial fibrillation promotion by endurance exercise: demonstration and mechanistic exploration in an animal model. J Am Coll Cardiol. 2013;62(1):68-77. https://doi.org/10.1016/j.jacc.2013.01.091 (Epub 2013 Apr 10).

191. Mozaffarian D, Furberg CD, Psaty BM, Siscovick D. Physical activity and incidence of atrial fibrillation in older adults: the cardiovascular health study. Circulation. 2008;118(8):800-7. https:// doi.org/10.1161/CIRCULATIONAHA.108.785626 (Epub 2008 Aug 4).

192. Benito B, Gay-Jordi G, Serrano-Mollar A, Guasch E, Shi Y, Tardif JC, Brugada J, Nattel S, Mont L. Cardiac arrhythmogenic remodeling in a rat model of long-term intensive exercise training. Circulation. 2011;123(1):13-22. https://doi.org/10.1161/ CIRCULATIONAHA.110.938282 (Epub 2010 Dec 20).

193. Morseth B, Graff-Iversen S, Jacobsen BK, Jørgensen L, Nyrnes A, Thelle DS, Vestergaard P, Løchen ML. Physical activity, resting heart rate, and atrial fibrillation: the Troms $\varnothing$ Study. Eur Heart J. 2016;37(29):2307-13. https://doi.org/10.1093/eurheartj/ ehw059 (Epub 2016 Mar 10).

194. Huxley RR, Misialek JR, Agarwal SK, Loehr LR, Soliman EZ, Chen LY, Alonso A. Physical activity, obesity, weight change, and risk of atrial fibrillation: the Atherosclerosis 
Risk in Communities study. Circ Arrhythm Electrophysiol. 2014;7(4):620-5. https://doi.org/10.1161/CIRCEP.113.001244 (Epub 2014 Jun 6).

195. Qureshi WT, Alirhayim Z, Blaha MJ, Juraschek SP, Keteyian SJ, Brawner CA, Al-Mallah MH. Cardiorespiratory fitness and risk of incident atrial fibrillation: results from the Henry Ford Exercise Testing (FIT) Project. Circulation. 2015;131(21):182734. https://doi.org/10.1161/CIRCULATIONAHA.114.014833 (Epub 2015 Apr 22).

196. Kamioka M, Hijioka N, Matsumoto Y, Nodera M, Kaneshiro T, Suzuki H, Takeishi Y. Uncontrolled blood pressure affects atrial remodeling and adverse clinical outcome in paroxysmal atrial fibrillation. Pacing Clin Electrophysiol. 2018;41(4):402-10. https://doi.org/10.1111/pace.13311 (Epub 2018 Mar 30).

197. Pathak RK, Middeldorp ME, Lau DH, Mehta AB, Mahajan R, Twomey D, Alasady M, Hanley L, Antic NA, McEvoy RD, Kalman JM, Abhayaratna WP, Sanders P. Aggressive risk factor reduction study for atrial fibrillation and implications for the outcome of ablation: the ARREST-AF cohort study. J Am Coll Cardiol. 2014;64(21):2222-31. https://doi.org/10.1016/j.jacc. 2014.09.028 (Epub 2014 Nov 24).

198. Malmo V, Nes BM, Amundsen BH, Tjonna AE, Stoylen A, Rossvoll O, Wisloff U, Loennechen JP. Aerobic interval training reduces the burden of atrial fibrillation in the short term: a randomized trial. Circulation. 2016;133(5):466-73. https://doi.org/ 10.1161/CIRCULATIONAHA.115.018220 (Epub 2016 Jan 5).

199. Proietti M, Boriani G, Laroche C, Diemberger I, Popescu MI, Rasmussen LH, Sinagra G, Dan GA, Maggioni AP, Tavazzi L, Lane DA, Lip GYH, EORP-AF General Pilot Registry Investigators. Self-reported physical activity and major adverse events in patients with atrial fibrillation: a report from the EURObservational Research Programme Pilot Survey on Atrial Fibrillation (EORP-AF) General Registry. Europace. 2017;19(4):535-43. https://doi.org/10.1093/europace/euw150.

200. Franklin BA, McCullough PA. Cardiorespiratory fitness: an independent and additive marker of risk stratification and health outcomes. Mayo Clin Proc. 2009;84(9):776-9. https://doi.org/ 10.1016/S0025-6196(11)60486-2.

201. Santos-Lozano A, Sanchis-Gomar F, Barrero-Santalla S, ParejaGaleano H, Cristi-Montero C, Sanz-Ayan P, Garatachea N, Fiuza-Luces C, Lucia A. Exercise as an adjuvant therapy against chronic atrial fibrillation. Int J Cardiol. 2016;15(207):180-4. https://doi.org/10.1016/j.ijcard.2016.01.140 (Epub 2016 Jan 9). 